\title{
My Syncretistic Faith-World Perspective
}

\section{Introduction}

This article introduces and sets the parameters of my faith-world based on whakapapa (genealogy) and whakapono (faith) and outlines my whakapapa links to whakapono: Patuheuheu and Ngāti Whare to Ringatū; Te Kooti's Te Umutaoroa prophecy gifted to Patuheuheu; Ngāti Manawa and Catholicism; and Ngāti Porou to Te Hāhi Mihinare. I also describe some of my experiences pertaining to Pentecostalism and Mormonism-a highly significant theological experience for me-and my lingering encounters with Taoism and Hinduism. Overall, I show how whakapapa is connected to whakapono and explore the facets of my faith that have shaped my personal theology.

\section{Syncretistic Beginnings}

I was raised within a highly syncretistic theological context, in which the remnants of ancient Māori traditions mixed seamlessly with Christianity. From an early stage, my faith-world was permeated with mysticism, healing, wairua (spirits), kaitiaki (spiritual guardians) and mate Māori (psychospiritual illnesses), along with Catholic, Presbyterian, Anglican and Pentecostal prayers and practices. Important practices came from the Catholic family of my great-grandfather, Hāpurona, including abstinence from meat on Friday and praying the Rosary. Although Hāpurona himself was not devout, his mother, Rangimaewa Fitzgerald, was. As reported by my grandmother, Rēpora, her grandmother, Rangimaewa, frequently fasted, prayed the Rosary and consumed fish instead of meat on Friday. Rangimaewa was of Ngāti Manawa and Irish descent, and Catholicism is a major denomination in Murupara, the home of the Ngāti Manawa.

My great-grandparents, Hāpurona Maki Nātana and Pare Koekoeā Rikiriki, were, respectively, Roman Catholic 
and Ringatū - a syncretistic and prophetic Māori faith that emerged in the 1830s with the teachings of Te Kooti Arikirangi Te Turuki. Their children were baptised alternately Ringatū and Catholic: the first child was Ringatū, the next was Catholic, and so on. Unlike the others, the youngest sibling was baptised Presbyterian, but practised as a devout Ringatu. My maternal grandmother, Rēpora, was the eldest daughter, preceded by two sons. Although baptised Catholic, the second son followed the Pentecostal path, or pakipaki (to clap) - a term referring to the tendency of Pentecostals to clap their hands during worship.

The Ringatū faith of my grandmother originally emerged from the intersections of colonisation, land loss and missionary Christianity. Te Kooti Arikirangi Te Turuki was an Anglican and had pursued a clerical life. He knew the scriptures and drew upon them-particularly the Old Testament-as a foundation for his new faith. He recognised similarities between Māori experiences and the story of the ancient Israelites and used these to encourage his followers to look to the future with the hope that, someday, Jehovah would deliver them all. My grandmother insisted on blessing all her mokopuna (grandchildren) whenever we travelled away from Murupara. She would sprinkle us with water from the Whirinaki River, making the sign of the cross on our foreheads while invoking the protection of Ihowā-Jehovah.

To my maternal grandmother's hapū, Patuheuheu, Te Kooti delivered a prophecy in 1886 at a place named Te Houhi. In the prophecy of Te Umutaoroa-the SlowCooking Earth Oven-Te Kooti promised that his child or successor would one day come to reveal an earth oven from which eight mauri (lifeforces) would emerge. They would restore what had been brutally lost to Harry Burt, a Pākehā (European) fraudster who spoke te reo Māori and manipulated both people and whakapapa to take ownership of the land. Te Kooti's prophecy addressed that desperate situation by creating a new theology of hope within and extending beyond his Ringatū faith.

Christianity is part of contemporary Māori life. It is mixed with pre-contact elements of our culture. At a tangihanga, one might see tikanga embrace and hold together a fusion of processes, symbols and codes in one place-the marae-at the same time. The wharenui- 
opened with pre-Christian incantations performed by a tohunga (priestly expert; practioner of karakia tahito-preChristian Māori incantations), who hides an object, fortified with a mauri (lifeforce)-is used as a church for Christian prayer. The priest or minister leads the Lord's Prayer in Māori and familiar hīmene (hymns), such as 'Tama ngākau mārie' and 'Whakāria mai', are sung above the strains of weeping and wailing. The marae àtea-a space for whaikōrero (formal oratory) and the domain of the Atua Tūmatauenga (ancestor-deity of war)-is similarly used like a church during tangihanga. The tūpāpaku (corpse) is in a place of importance, surrounded by close relatives, with a priest or minister and kaumātua (elders) nearby and other mourners arranged in rows, with an aisle down the middle of the marae atea leading to the waharoa (gateway).

Before colonisation, our indigenous spirituality mirrored our cultural and spiritual relationships with the environment. Our belief system is based on ngā Atua, located within the world around us, which refers to ancestor deities with continuing influence over particular domains (Moorfield, 2011). Many authors capitalise the word Atua when referring to the Christian God and do not capitalise the word when referring to ngā Atua. However, following the example of Davidson (2004), I capitalise it in both instances. Since the arrival of Christianity to Aotearoa New Zealand in the early 19th century, Māori have tried to make sense of Christian theology and to adapt it to our needs. From the early 1830s, many syncretistic Māori prophet movements emerged to resist the inevitable loss of land under British colonisation. The prophets saw parallels between themselves and Israel and looked to the liberation theology of the Old Testament for inspiration and hope. Within mainstream Christian movements too, we engaged with Christianity in uniquely Māori ways, filtering and syncretising the new theology through and with our iwi, hapū and whānau epistemologies.

\section{Upraised Hands: Patuheuheu, Ngāti Whare, Ngāi Tūhoe and the Ringatū Faith}

As I was raised in a Ringatū faith context, it is important here to understand Te Kooti's life and ministry, as this lays the foundation for the religion that he left behind: the one that has informed my faith. The central theme of Te Kooti's ministry is the notion that Māori must 
hold on to their land. The enigmatic ideas left behind by Te Kooti as prophecy-as waiata (songs) and in other formscan be interpreted in multiple ways. However, to decode meaning within them, it is crucial to analyse his words using spiritual and political lenses.

Te Kooti's birth was prophesied by the matakite (prophet, seer, clairvoyant) Toiroa (Belich, 1986; Binney, 1997; Elsmore, 2008; Tarei, 2011). According to Tarei (2011), Toiroa said to Turakau, the prophet's mother, 'my child is within you; lightning in hell; lightning in heaven; the Lord of heaven in the man' (p. 140). While Elsmore (2008) claimed that Te Kooti was born in 1830, one account from Delamere asserted that he was born in 1814 (Binney, 1997), which coincides with the arrival of Christianity through the Anglicans. According to Tarei (2011), Te Kooti may have been born in 1812, 1814 or 1830.

Te Kooti claimed Toiroa was his ancestor (Binney, 1997). Toiroa associated the birth of Te Kooti, who was originally named Arikirangi, with darkness. He expressed this in the following waiata:

Tiwha tiwha te pō.

Ko te Pakerewhā

Ko Arikirangi tenei ra te haere nei.

Dark, dark is the night.

There is the Pakerewhā

There is Arikirangi to come. (Te Kooti, 1866-1890)

Te Kooti was connected to the predicted arrival of Pākehā, an event associated with evil and the coming of a new God: 'Te ingoa o to ratou Atua, ko Tama-i-rorokutia, he Atua pai, otira, ka ngaro anō te tangata. The name of their God will be Tama-i-rorokutia (Son-who-was-killed), a good God; however, the people will still be oppressed' (Binney, 1997, p. 12).

Te Kooti's troublesome childhood was no less dramatic than the prophesies of his birth, as his father attempted to kill him many times (Binney, 1997). His ability to escape these attempts became one of his defining traits (Mackay, 1949). Consecrated to Tūmatauenga, the Atua of war, Te Kooti was educated at whare wānanga (traditional place of higher learning) in which tohunga (priestly experts) taught history, genealogy and religious practices to the sons of rangatira (chiefs). 
Te Kooti received a Christian education through the Anglican Church and, by the early 1850s, he had been exposed to three major denominations: the Anglican, Catholic and Wesleyan churches (Binney, 1997). He received an Anglican baptism under the name Te Kooti, a transliteration of 'Coates'. There are several explanations for why Te Kooti chose this name. It was the name of the lay secretary of the Church Mission Society, C. Dande(r)son Coates (Binney, 1997; Mackay, 1949), which Te Kooti had seen on official notices during a trading trip to Auckland (Cowan, 1938). However, according to Williams (1999), Te Kooti told James Cowan that 'Te Kooti was the transliteration of "By Order of the Court"' (p. 76), the irony of which, Williams comments, must have amused him.

Te Kooti obtained Pākehā education through the Anglican mission and gained an intimate knowledge of the Bible (Binney, 1997; Elsmore, 2008; Greenwood, 1942; Tarei, 2011). According to Mackay (1949), he was an established horseman and engaged in various occupations including farm, bush work and work at sea on several schooners. The skills Te Kooti gained through his work at sea would be beneficial in the future, when he and many others escaped imprisonment on a remote outer island on a schooner (Binney, 1997). According to Tarei (2011):

Some people have said this [the mission school] is where he got his knowledge of scripture. But I do not believe it. His breadth and depth of knowledge-his understanding of scripture-was far greater than any missionary could have given him. It was inspiration. (p. 140)

Although he aspired to be an Anglican clergyman, by 1852, Te Kooti had become infamous in the Tūranga tribal area for his involvement with a group of young Māori protesting over land rights, looting and charging pasturage and anchorage to settlers (Binney, 1997). Te Kooti's involvement in the land politics of the 1850s and early 1860 s at Türanga hindered the progress of settlers and challenged the chiefs of Rongowhakaata and Ngāti Maru (a hapu of Rongowhakaata). In return, these leaders played a significant role in sending $\mathrm{Te}$ Kooti to prison on the Chatham Islands in 1866 (Binney, 1997).

From 1860, the iwi of the Waikato and Taranaki areas were at war with the Crown. However, the Türanga chiefs made it their policy to remain neutral to maintain control 
(Binney, 1997). The determined independence of the Tūranga chiefs ensured they did not join the Kingitanga movement-a Māori political institution founded in 1858 that sought to unify Māori under one native sovereign-and continued to regulate European settlement (Binney, 1997).

In 1865, the Pai Mārire religious movement spread to Tūranga (Binney, 1997; Salmond, 1976). The Pai Mārire claimed to come in peace, and it was their intention to unite the Māori under one authority (Binney, 1997). However, civil war broke out and the Crown provided arms to one side to serve their own interests (Binney, 1997). While it remains unclear which side Te Kooti fought on, it is likely he acted out of concern for land at Tūranga (Binney, 1997).

Accused of being a Hauhau-a member of the Pai Mārire movement, Te Kooti was arrested in 1866 (Binney, 1997; Davidson, 2004; Elsmore, 2008; Salmond, 1976; Tarei, 2011; Walker, 2004) and on 5 June 1866, he was sent to Wharekauri (Chatham Islands) (Binney, 1997; Davidson, 2004; Elsmore, 2008; Tarei, 2011; Walker, 2004). Figure 4 shows Māori Hauhau prisoners on the Napier foreshore, awaiting transportation to Wharekauri. Te Kooti is believed to be among this group. When the prisoners arrived at Wharekauri, they were posted at Waitangi (Binney, 1997; 'Prisoners' Work List 1', March 1866-1867; Russell, 1866). The prisoners were considered whakarau (political offenders) and were incarcerated without trial (Rolleston, 1868; Wellington Independent, 1869). 


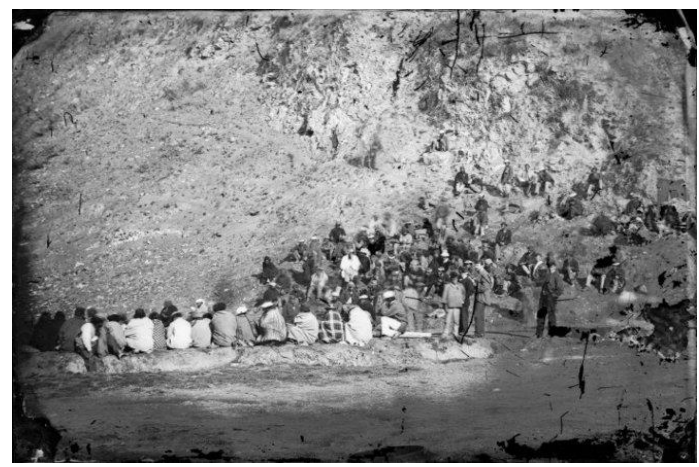

Figure 1. Māori Hauhau prisoners on Napier foreshore(Robson, 1866).

Conditions on the island were harsh, resulting in high rates of illness and death among the captives (Binney, 1997). According to Belich, "Te Kooti and his fellow exiles found life on the Chathams hard and cold ... abuse and beatings were common, and the guards spent most of their time drunk' (McRae \& Stephens, 1998, n.p.). Greenwood (1942) stated:

The prisoners were forced to under-go medical inspection of an obscene nature, and much cruelty and immorality was reported ... the stories handed down of the behaviour of the guards are not flattering to the Pākehā, especially as the Māori was making some semblance of religious observance. (p. 22)

Under these difficult conditions, Te Kooti became unwell. He was treated for chronic asthma and declared unfit for work by a doctor ('Medical report for the month ending 31 March 1867', 1867). During his sickness, Te Kooti studied the books of Joshua, Judges and the Psalms (Greenwood, 1942) and experienced prophetic visions and revelations (Binney, 1997; Davidson, 2004; Elsmore, 2008; Tarei, 2011; Walker, 2004). He claimed the Spirit told him to 'Rise! Come forth! You are spared to be made well, to be the founder of a new church and religion, to be the salvation of the Maori people and to release them from bondage' (Ross, 1966, p. 30). Like Moses, Te Kooti had been called to liberate his followers from oppression. This spurred the beginnings of a new Māori faith (Belich, 1986; 
Binney, 1997; Elsmore, 2008; Ross, 1966; Salmond, 1976; Walker, 2004). Belich claimed that it was Te Kooti who restored their hope. ... He began preaching a new religion, called Ringatū - the upraised hand' (McCrae \& Stephens, 1998, n.p.).

Te Kooti claimed he was influenced many times by the spirit of God at Wharekauri and that he was a prophet of God (Binney, 1997). Despite solitary confinement, he preached and conducted religious services in secret (Binney, 1997). He developed a commanding influence over most prisoners and convinced them that, by following his faith, they would be delivered from captivity (Binney, 1997; Tarei, 2011).

Within the framework of his faith, Te Kooti instructed the people to discard their Pai Mārire beliefs and look to the scriptures for inspiration. They identified with the bondage suffered by the ancient Israelites under Egyptian rule (Binney, 1997; Greenwood, 1942) and embraced the Book of Exodus, which promised 'the return' (Walzer, 1985).

Belich stated that the 'prisoners had been told that their exile was temporary and were promised a fair trial. When nothing happened, they began to lose hope; they feared they would never see their homes again' (McCrae \& Stephens, 1998, n.p.). When the prisoners realised their imprisonment was not temporary and that their lands were under threat of government confiscation, Te Kooti's teachings were absorbed more readily, accelerating the growth of the Ringatū following (Binney, 1997).

When Te Kooti's ministry took hold in 1868, the people became increasingly dissatisfied with their predicament. They fixated on leaving the island, drawing strength from Te Kooti's predictions of escape (Binney, 1997). Te Kooti predicted the sign for escape would be two ships in the harbour, which came to pass on 3 July 1868, when the schooner Rifleman and the small ketch Florence were both in the harbour (Auckland Star, 1914; Belich, 1986; Binney, 1997).

Te Kooti's flag was hoisted over the prisoner's quarters, signalling the prisoners to undertake his plan of escape (Binney, 1997). Te Kooti and his followers seized the Rifleman, telling the crew their lives would be spared if they took the prisoners back to Aotearoa New Zealand, which they agreed to do (Belich, 1986; Binney, 1997). 
On 9 July 1868, the Rifleman arrived south of Poverty Bay at the relatively empty Whareongaonga. From the perspective of the escapees, Jehovah had delivered them to the mainland (Binney, 1997; Greenwood, 1942; Walker, 2004). Elsmore (2008) maintained:

Te Kooti's escape with his band of followers from their place of exile, over the sea to their native land, was to their mind very much a latter-day flight out of Egypt, with the ship (the Rifleman) a veritable ark of deliverance. It is said that the prophet stated when he boarded the boat, "the day, the vessel, the salvation, are from God'. (p. 135)

His followers were instructed to fast until the ship was unloaded and a pig and chicken were sacrificed as a burnt offering to the Lord (Binney, 1997), during which Te Kooti's adherents stood in prayer with their right hands raised in praise to God-a physical gesture that would remain entrenched in Te Kooti's Ringatū faith (Binney, 1997). Although Te Kooti initially instructed his followers to bind their newborn babies to the firewood in preparation for sacrifice, just like the story of Abraham's sacrifice, this was a test, and the chicken and pig were sacrificed instead (Binney, 1997).

On 14 July 1868, Te Kooti and his followers left Whareongaonga on a slow and arduous journey to the King Country (Waikato) to peacefully enact a new prophetic order (Binney, 1997). Te Kooti would only fight if attacked (Kempthorne, 1868; Williams, 1868). He intended to challenge King Tâwhiao-the political and spiritual leader of the Kingitanga movement (Auckland Star, 1914).

Te Kooti's war began on 20 July 1868, when government troops and Māori were defeated at Pāparatū (Belich, 1986; Binney, 1997). Numerous advantages contributed to Te Kooti's success. His efficacious escape from Wharekauri was proof to his followers that he wielded authority and power from God (Binney, 1997). Te Kooti also had an exhaustive knowledge of the local topography and the ability to deal effectively with Pākehā (Belich, 1986; Binney, 1997). Further successes were attained on 24 July 1868 at Te Kōneke and 8 August 1868 at Ruakituri Gorge (Belich, 1986; Binney, 1997). In these battles, Te Kooti was shot in the ankle and retired to Puketapu, near Lake Waikaremoana, where he was joined by a few Tūhoe from Te Whāiti (Binney, 1997). 
After King Tāwhiao rejected Te Kooti's request to enter his territories (Binney, 1997), Te Kooti returned home to Poverty Bay, to his lands at Matawhero, only to find that some of his lands were in the possession of magistrate Reginald Biggs (Binney, 1997; Walker, 2004).

On 9 November 1868, Te Kooti attacked Matawhero and a neighbouring village, killing 50-60 people (Belich, 1986; Binney, 1997; Walker, 2004). Te Kooti was exact in selecting those to be killed; Biggs and Captain James Wilson were 'Pharaoh's overseers' (Binney, 1997). Biggs, his wife, his child and their nurse were killed and bayoneted; their house and Wilson's house were among the first to be burned. Te Kooti sought to destroy anyone who wronged him. According to Binney (1997), all those killed were shot or bludgeoned and then impaled with a sword or bayonet. The use of the sword refers to Book of Psalms passages, which Te Kooti instructed his men to sing:

But those that seek my soul, to destroy it, shall go into the lower parts of the earth.

They shall fall by the sword: they shall be a portion for foxes.

But the king shall rejoice in God; every one that sweareth by him shall glory: but the mouth of them that speak lies shall be stopped. (Psalms 63:9-11 KJV)

The events of November 1868 were believed by some to partially fulfil Toiroa's prophecy about the darkness associated with Te Kooti. They were carefully planned by Te Kooti (Binney, 1997). The Pākehā men were killed because of their involvement in the militia and because they were living on land to which Te Kooti had legitimate claim. The Māori were killed because of their disloyalty and their readiness to collaborate with the government's land schemes. Māori and Pākehā women and children were killed during warfare (Binney, 1997).

Te Kooti's desire to seek utu against those who wronged him is reflective of the Old Testament, such as the vengeful actions of King Saul (Comay, 2002; Winiata, 1967; 1 Samuel $23 \mathrm{KJV})$. Sometimes simply translated as revenge, utu is the process of restoring balance between groups in which social relations have been disturbed (Moorfield, 2011). The Māori concept of utu justified acting to restore balance. Old Testament law offered further validation for reprisal in the name of Jehovah (Elsmore, 2008) and provided justification for revenge: thou shalt 
give life for life, eye for eye, tooth for tooth, hand for hand, foot for foot, burning for burning, wound for wound, stripe for stripe' (Exodus 21:23-25 KJV).

Te Kooti and his entourage of $500-800$ people, including a fighting force of approximately 200, moved through Poverty Bay, raiding and gathering supplies and approximately 300 Māori captives (Binney, 1997). A contingent comprising Ngāti Porou and government troops pushed Te Kooti to Ngātapa pā (fort).

An assault on Te Kooti and his followers at Ngātapa commenced on 5 December 1868 and the fighting continued for the following month (Newland, 1868). When it appeared that Te Kooti's defences had been breached (Binney, 1997), he and his followers attempted to escape by lowering themselves down the northern cliffs (see Kotuku, 1921), a route thought impossible to take (Whitmore, 1868). Although Te Kooti escaped, many of his group were captured and shot (Binney, 1997).

After the battle at Ngātapa, Te Kooti and his followers took refuge in the Te Urewera area (Belich, 1986; Binney, 1997; Walker, 2004) and, at Tāwhana, Ngāi Tūhoe sealed a pact with Te Kooti, on what was thought to be 20 March 1869 , that strengthened the latter's resolve in his prophetic mission (Belich, 1986; Binney, 1997). Binney (1997) disputed this date. Her historical calculations indicated the more likely date as 2 March 1869, as Te Kooti was at Tāwhana at this time, but was elsewhere on 20 March. According to Binney (1997), Tūhoe 'gave him their land and their loyalty' (p. 154), probably symbolically as a token of their link. In return, Te Kooti established a covenant with Tūhoe, similar to the promises made between Jehovah and Moses in the Old Testament:

You drew me out of darkness. You have sent the people into the flames of the fire, into the tests, since the landing [this] has gone on. Listen, this is what I have to say, 'I take you as my people, and I will be your God; you will know that I am Jehovah'. You are the people of the covenant. (Binney, 1997, p. 154)

The biblical similarity Binney (1997) refers to is probably found in the Book of Exodus 6:7 (KJV): 'and I will take you to me for a people, and I will be to you a God: and ye shall know that I am the Lord your God, which bringeth you out from under the burdens of the Egyptians'. 
On 10 April 1869, Te Kooti attacked Mōhaka in the northern Hawke's Bay area (Belich, 1986; Binney, 1997). Painted on a rafter inside Tama-ki-Hikurangi wharenui at Patuheuheu marae in Waiohau is a motif that 'shows the act of bayoneting, following Psalm 63, understood to refer to the killings at Mōhaka in 1869' (see Figure 5; Binney, 1997). During this attack by Te Kooti, 'people were caught sleeping and all were killed, even babies, who were thrown up in the air and bayoneted' (Neich, 1993, p. 261).

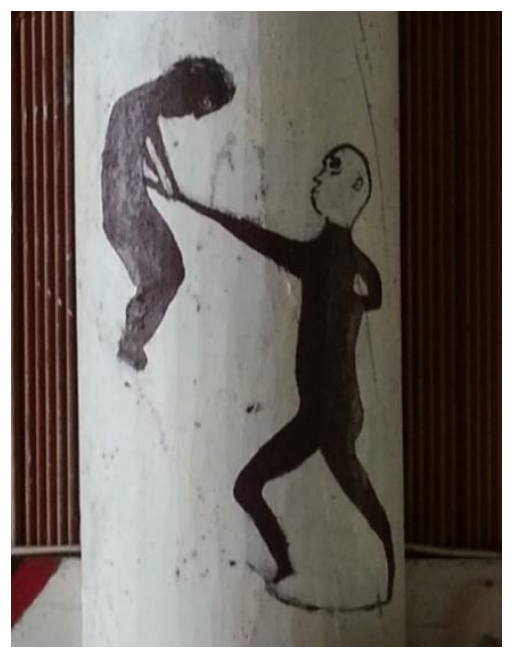

Figure 2. Bayonet scene on heke (rafter) inside Tama-kiHikurangi wharenui, Patuheuheu marae, Waiōhau

Through covenant, Tūhoe were committed to defending their prophet. However, Colonel G. S. Whitmore initiated a scorched earth policy aimed at terminating Tūhoe's capacity to protect Te Kooti (Belich, 1986; Binney, 1997; Walker, 2004; Whitmore, 1869). Major Rōpata Wahawaha's Ngāti Porou forces moved in as well, capturing refugees, razing Tūhoe villages and destroying crops (Belich, 1986; Binney, 1997). Due to the tragedies suffered by Tūhoe, Te Kooti was asked to leave their territory (Binney, 1997). 
Throughout 1869, Te Kooti travelled across the country, simultaneously attempting to fight the Crown, lead his people and garner support for unhindered passage or fighters for his cause (Belich, 1986; Binney, 1997; Elsmore, 2008). Between 1870 and 1871, the Tùhoe chiefs were compelled to surrender when their homes and food supplies were plundered by Māori forces from Te Arawa, Ngāti Kahungunu and Ngāti Porou. These Māori were both fulfilling the requirements of utu for past grievances and serving the Crown's agenda (Belich, 1986; Binney, 1997). Although Te Kooti predicted that Tühoe would betray him (Binney, 1997), Belich (1986) asserted that this did not occur. It is certain that Te Kooti's understanding of Pākehā, coupled with staunch support from Tūhoe, helped him escape (Alves, 1999; Belich, 1986; Binney, 1997).

Te Kooti continued to evade his pursuers. On 15 May 1872, he arrived in the King Country, where he asked for refuge at Tokangamutu (Belich, 1986; Binney, 1997). The King Country, ruled by the Kingitanga, was off limits to the government and settlers at this time. In September 1873, when Te Kooti accepted Tāwhiao's policy of peace (unless under attack), he was granted protection (Belich, 1986; Binney, 1997).

Te Kooti lived in Te Kuiti from 1873 until 1883. Here, he developed the rituals, festivals, texts, prayers, hīmene and waiata of the Ringatu faith. In 1883, at the insistence of Rewi Maniapoto, Te Kooti was pardoned by the Crown, but was never allowed to return to Poverty Bay. He lived in exile for the remainder of his life (Belich, 1986; Binney, 1997; Greenwood, 1942). Te Kooti then founded a religious community. He attempted to make peace with his enemies and instructed his followers to understand the law, claiming that only the law can be used against the law (Binney, 1997). By 1891, Te Kooti's associations with King Tāwhiao and Rewi Maniapoto had weakened so much that Te Kooti once again rejected the Kingitanga (Binney, 1997).

Te Kooti negotiated with the Crown for land on which to establish a settlement for himself and his followers. In 1891, he was given 600 acres at Wainui on the Ōhiwa Harbour (Binney, 1997). In February 1893, Te Kooti travelled to his new settlement. On the way, a cart under which he was resting fell on him. As he prophesied, this accident would ultimately cause his death (Binney, 1997; Tarei, 2011). Te Kooti died on 17 April 1893 in Rūātoki, but 
his body was hidden by faithful followers (Binney, 1997; Greenwood, 1942; Williams, 1999). After a turbulent youth, and having lived through a political and blood-drenched war, Te Kooti spent the final two decades of his life devoted to peace, the law and the gospel (Binney, 1997).

One of the most significant of Te Kooti's waiata relating to the ways in which my identities as Patuheuheu, Ngāti Whare and Ngāi Tūhoe interact is Kāore te pō nei mōrikarika noa. According to McLean and Orbell (2004), Te Kooti visited Tūhoe and composed and performed this waiata tohutohu (song of instruction) in 1883 in support of the iwi's stand against aggressive land surveying by Pākehā. In the case of this waiata, McLean and Orbell (2004), claimed that it can also be described as a waiata matakite (prophetic song).

However, Binney (2009a) argued that, after 1872, Te Kooti did not revisit Te Urewera until 1884. She assigns the performance of his prophetic waiata to the opening of the Marakoko wharenui-built in Te Kooti's honour by Ngāti Whare and Tūhoe at Te Murumurunga near Te Whāiti-in January 1884. However, in his prophetic fashion, Te Kooti changed the name of the wharenui to Eripitana (Binney, 2009a; see Figure 6), which is known in Te Kooti's secret glossolalic language-te reo kē (other/strange language). In one interpretation from 1883, this name meant: 'The Prediction of One to Follow' (Binney, 1997, p. 612, n. 59), while, in a much earlier 1869 prophecy, it referred to the promise of the salvation of the people (Binney, 1997). 


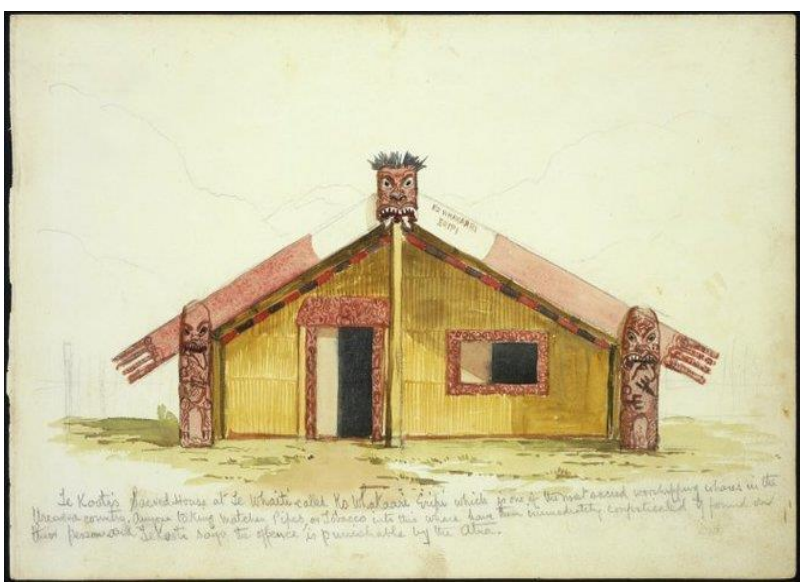

Figure 3. Eripitana wharenui, 1891(Thomas, 1891).

As Te Kooti approached the wharenui, his horse shied, and he noticed an inverted carved figure. Salmond (1976) claimed that the carver of Eripitana had 'accidentally inverted a carving motif' (p. 67). Salmond (1976) implied that it was owing to the error of the inverted carving that Te Kooti expressed his prophetic words on the pou mua-a front post of the wharenui (Moorfield, 2011; see Figure 7): 'its wide mouth turned upside-down, ready to devour everything around it' (Binney, 1997, p. 326). Te Kooti then uttered a prophecy of destruction:

Kāinga katoatia a ko te paepae o te whare nei ki roto [ka] kati tonu hei huihuinga mo nga morehu.

It will be completely consumed, and only the threshold of this house inside will remain as the meeting place for the survivors. (Binney, 1997, p. 326) 


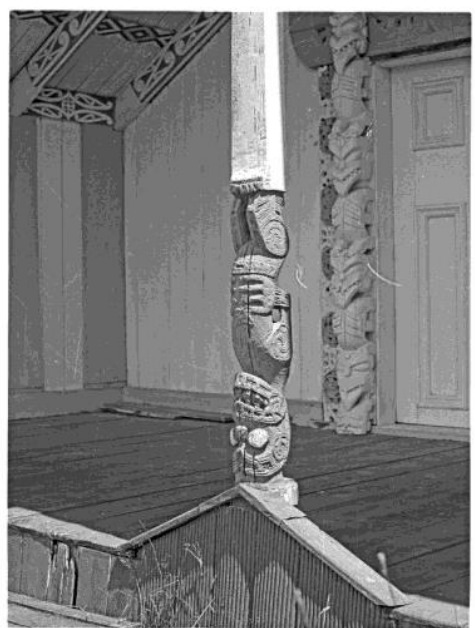

Figure 4. Inverted pou mua of Eripitana wharenui, 1970(Mead, 1970).

Binney (1995) claimed that this prophecy soon became associated with land loss at Te Whāiti. These stories are well known by the elders of Ngāti Whare because of the way in which the history is embedded and immortalised within Te Kooti's prophecy. The late Robert Taylor, an esteemed elder of Ngāti Whare, opined:

It's well documented about the prophecy of Te Kooti on how he came up in here and when his horse shied at seeing this tekoteko here and then he came out with the prophecy about Ngāti Whare: 'Your lands will be lost to foreigners'-which was the Crown. (Hakaraia \& Stephens, 2013, n. p.)

The tekoteko refers to a carved figure on the gable of a wharenui (Moorfield, 2011). According to Binney (1995), the waiata was probably composed as a response to Tühoe's request for their lands to be under the protection of Te Kooti's spiritual authority.

Te Kooti's waiata tohutohu begins:

Kāore te pō nei mōrikarika noa!

Te ohonga ki te ao, rapu kau noa ahau.

Ko te mana tuatahi ko te Tiriti o Waitangi,

Ko te mana tuarua ko te Kooti Whenua, 
Ko te mana tuatoru ko te Mana Motuhake, Ka kīia i reira ko te Rohe Pōtae o Tūhoe, He rongo ka houhia ki a Ngāti Awa.

He kino anō rā ka āta kitea iho

Ngā mana Māori ka mahue kei muri!

Alas for this troubled night!

Waking to the world I search about in vain.

The first authority is the Treaty of Waitangi,

The second authority is the Land Court,

The third authority is the Separate Mana,

Hence the Rohe Pōtae (Encircling Borders) of Tūhoe.

A peace made with Ngāti Awa.

It would indeed be an evil thing 269)

To abandon the mana of Māori! (Binney, 2009a, p.

Te Kooti critically reflects on the three authorities that affected the Tūhoe people: the mana (authority) of the Treaty of Waitangi, which Tūhoe did not sign; the mana of the land court; and the 'separate mana'-Tūhoe's mana over te Rohe Pōtae o Tūhoe-the encircling borders of Tūhoe (Binney, 1997, 2009a). Clearly, Te Kooti was aware of the political implications of these three authorities and the devastating effects they would have on Tūhoe. According to Binney (2009a), 'the Treaty and the land court were "creations" of the new world, shaping and influencing the people's choices; the Rohe Pōtae of Tūhoe was their "separate mana", standing apart' (p. 270). In the lines, 'He kino anō rā ka āta kitea iho/Ngā mana Māori ka mahue kei muri!' (Binney, 2009a, p. 269), Te Kooti warns that it would be wrong to forsake the mana of Māori. This is sometimes interpreted as a forewarning that Tühoe authority over the rohe pōtae (tribal territory) would be manipulated and redefined under Pākehā law.

In the line, 'He rongo ka houhia ki a Ngāti Awa', Te Kooti reminds Tūhoe of the 1830s tatau pounamu between Tūhoe and Ngāti Awa, which is an enduring peace agreement. This peace treaty was negotiated by my fifthgreat-grandfather, the Ngāti Rongo and Patuheuheu chief Koura, who represented Tūhoe, and the Ngāti Pahipoto chief, Hātua, who represented Ngāti Awa (Boast, 2002; Mead \& Phillis, 1982). Te Kooti's reminder to Tūhoe could be interpreted as a political strategy, suggesting that continued peace between the tribes should be maintained 
to channel collective strength against the forces of colonisation. Te Kooti's waiata tohutohu continues:

Ka uru nei au ki te ture Kaunihera,

E rua aku mahi e noho nei au:

Ko te hanga i ngā rori, ko te hanga i ngā tiriti!

Pūkohu tāiri ki Pōneke rā,

Ki te kāinga rā i noho ai te Minita

When I submit to the law of the Council,

There are two things I would do:

Building roads, and building streets!

Yonder the fog hangs over Wellington, 270)

The home of the Minister. (Binney, 2009a, pp. 269-

Te Kooti admonishes Tūhoe that if they accept 'te ture Kaunihera' (the law of the Council), they would be forced to build the very roads and streets that they opposed so vehemently (Binney, 1997), which would slice through and literally 'open up' the land to Pākehā invasion (Binney, 2009a). His waiata resumes:

Ki taku whakaaro ka tae mai te Poari

Hai noho i te whenua o Kootitia nei;

Pā rawa te mamae ki te tau o taku ate.

E te iwi nui, tū ake i runga rā,

Tirohia mai rā te hē o aku mahi!

I fear that the [Land] Board will come

To occupy this land adjudicated by the Court,

And I am sick at heart.

Oh great people, stand forth

Examine whether my works are wrong! (Binney, 2009a, pp. 269-270)

Te Kooti warned Tūhoe about the government boards that sought power over Māori lands (Binney, 2009a). In the 1884 historical context, Binney (2009a) maintained that this is probably a reference to the wasteland boards that were established in 1876, with the power to control Māori lands that were leased, purchased or confiscated by the Crown. However, Binney (2009a) also contended that the meanings extrapolated from Te Kooti's waiata 'present to different times different premonitions' (p. 27). Therefore, when the reference to the boards is interpreted from a future perspective, it can be associated with the Māori land boards (Binney, 2009a). The Māori land boards were designed to oversee the extensive land acquisition for the Crown and were established under the Māori Land 
Settlement Act 1905 when it was realised that voluntary leasing of Māori land was not meeting Crown targets (Hill, 2004). According to Binney (2009a), these boards were 'powerful and bureaucratic', taking land away from Māori 'through partition, vestments, and piecemeal purchase' ( $\mathrm{p}$. 270).

In concluding his waiata tohutohu, Te Kooti advises the people not to sell, but to remain on their lands:

Māku e kī atu, 'Nōhia, nōhia!'

Nō mua iho anō, nō ngā kaumātua!

Nā taku ngākau i kimi ai ki te Ture,

Nā konei hoki au i kino ai ki te hoko!

Hii! Hai aha te hoko!

I say to you, 'Stay, Stay!'

It comes from former ages, from your ancestors!

Because my heart has searched out the Law,

For this reason I abhor selling!

Hii! Why sell! (Binney, 2009a, pp. 269-270)

In the line, 'Nā taku ngākau i kimi ai ki te Ture', Te Kooti claimed to have examined the 'Law' with his ngākau or mind-heart, finding that it was iniquitous for the land to be sold (Binney, 1997). McLean and Orbell (2004) claimed that Te Kooti's use of the word ture, or law, refers to his religious beliefs and teachings. Meanwhile, according to Moorfield (2011), ngākau refers to the seat of affections, heart and mind. However, Salmond's (1985) definition of ngākau as mind-heart, or the entrails where thought and feeling are manifested, is used here.

At the end of Te Kooti's visit to Eripitana, he and some Te Urewera leaders travelled to Te Teko and Whakatāne. The leaders offered Te Kooti mana over the rohe pōtae lands (Binney 2009a). However, Te Kooti stated that he did not want their lands, but advised them constantly and consistently to remain on and take care of them (Binney, 2009a), emphasising the crucial importance of the critical and tactical thinking embedded within this waiata.

While Te Kooti's ministry began in resistance and bloodshed, it ended in peace as 'the prophets had turned to pacifism as an alternative means of expressing the Maori dynamic of self-determination' (Walker, 1984, p. 271). After four years of violence and successfully using guerrilla tactics to avoid capture, Te Kooti retreated in peace. According to Belgrave (2018), 'after his escape into the sanctuary of the Rohe Pōtae, he peaceably promoted the 
building of new marae until he was formally pardoned in 1883' (p. 215). Te Kooti inspired the building of the wharenui Tama-ki-Hikurangi, once located at Te Houhi and later moved to Waiōhau following Patuheuheu's loss of their land at Te Houhi. When Patuheuheu lost their land, Te Kooti gifted to them a prophecy called Te Umutaoroathe Slow-Cooking Earth Oven.

\section{Te Umutaoroa: Te Kooti's Slow-Cooking Earth Oven}

In the 19th century, Patuheuheu, Ngāti Haka, Ngāti Manawa and Ngāti Whare occupied the Te Houhi, Waiohau and Horomanga areas (Binney, 2009a). Patuheuheu hapu were followers of Te Kooti, whom the Crown considered a rebel. This association resulted in the hapu being forced by the government to leave its home in the Rangitaiki Valley and the imprisonment of its members at Te Puttere, near Matatā in the eastern Bay of Plenty (Binney, 2001, 2003, 2009a, 2010; Paul, 1995). Binney (2003) described Te Pūtere as like a concentration camp:

I used the term 'concentration' camp because people were 'concentrated' there. Everyone agreed it was bad land, situated amongst sand dunes, and unsuitable for cultivation. It was a 'concentration camp' for people who were forced to live largely on government handouts of potatoes until they went home in 1872-73. (pp. 2-3)

In 1872, the Patuheuheu hapū were released and returned to their lands at Te Houhi, which became their main kāinga (home) (Arapere, 2002; Binney, 2001, 2003, 2009a, 2010; Paul, 1995). By most accounts, the wharenui Tama-ki-Hikurangi, 'a meeting house built for Te Kooti at Te Houhi (near Galatea) by the Patuheuheu people, a hapu of Tūhoe' (Binney, 1997; see also Neich, 1993), was commissioned there. On 28 November 1893, Te Houhi School was opened (Stokes, Milroy \& Melbourne, 1986) with Mēhaka Tokopounamu-my third great grandfatheras the first school chairman (Binney, 2009a). After Patuheuheu's exodus from Te Houhi in 1907, a school was opened in their new settlement at Waiōhau on 6 May 1918 (Binney, 2009b). Mēhaka Tokopounamu's son, Rikiriki Mēhaka, was the chairman of the school committee (see Simon \& Smith, 2001).

With their homes and a school in place, the community of Te Houhi would have seemed stable and secure, particularly in contrast to the dreadful conditions 
endured at Te Pūtere. However, the 1880s, 1890s and early 20th century brought great uncertainty for Patuheuheu as the colonial maps that demarcated the land were redrawn yet again. A ruinous act of deceit was on the horizon and Patuheuheu's home and way of life was again at risk. Harry Burt, a licensed Native Land Court interpreter and supposed friend of the prophet Te Kooti, coordinated duplicitous land transactions in the mid-1880s that ultimately led to the displacement of Patuheuheu from their land at Te Houhi in 1907 (Binney, 1997, 2001, 2009a, 2010; Boast, 2008).

Harry Burt, or Hare Paati as he was known to the hapū, was not Māori (Auckland Star, 1905, p. 5), but was a speaker of te reo Māori and worked as an interpreter for the Native Land Court (Binney, 1997, 2001, 2009a, 2010; Boast, 2008). The Native Land Court system-an effective instrument for alienating Māori from their land-was used by Burt to underhandedly acquire the land from beneath the hapū (Binney, 1997, 2001, 2009a, 2010; Boast, 2008). This event is known as the Waiōhau Fraud (Boast, 2002).

Binney (2001) contended that Harry Burt belonged to a "sub-culture": a visible group of early settled Pākehā men who lived with Māori women' (p. 162) and spoke the native language. Burt was a trickster who hid behind a cloak of colonial hybridity (Binney, 1997, 2001, 2010) and 'claimed friendship and more-kinship—with Māori .... He was a manipulator, who created a mood and experience of confidence and trust. $\mathrm{He}$ was a swindler who outmanoeuvred a prophet' (Binney, 2001, p. 148).

The block of land on which Te Houhi was located was known in the Native Land Court in 1878 as Waiohau 1 (Arapere, 2002; Binney, 2001, 2009a, 2010; Paul, 1995). In January 1886, a committee of 12 Tūhoe men, joined by Te Kooti, met with Burt to negotiate. They asked Burt to accept 1000 acres of land to satisfy his land needs (Binney, 2001, 2007c, 2009a, 2010). However, Waiōhau 1 was illegally brought before the court for partition by Burt, operating under the pseudonym Hare Rauparaha (Waiariki Māori Land Court, 1886, 16 February). Using the pseudonym, Burt exploited his position as an interpreter in the Native Land Court and fabricated a new identity by embezzling whakapapa and mana from the name of the famous Ngāti Toa chief, Te Rauparaha (Binney, 2001, 2007c, 2009a, 2010). Burt's partition was to establish half 
of the block-7000 acres-as Waiohau 1B in the name of two Ngāti Manawa owners: Pani Te Hura, also known as Peraniko Ahuriri, and Hira Te Mumuhu (Binney 2001, 2007c, 2009a, 2010; Stokes et al., 1986). These men, manipulated by Burt, immediately sold the newly established Waiōhau 1B in the court foyer, witnessed by Judge H. T. Clarke and Harry Burt (Binney, 2001, 2009a, 2010).

Burt's deceitful acts were examined by a judicial inquiry in 1889, established through a parliamentary recommendation in response to a petition from Mēhaka Tokopounamu and 86 others (Binney, 2001, 2009a, 2010; Paul, 1995). The petition claimed that Burt had dishonestly obtained ownership of Waiōhau 1B by coercing people to sell their shares to him (Binney, 2001, 2009a, 2010; Paul, 1995). According to Mēhaka Tokopounamu's petition, Burt purchased the shares of at least 40 people (Paul, 1995). Te Kooti renamed $\mathrm{Te}$ Houhi to $\mathrm{Te}$ Umutaoroa, and told Mèhaka and the other petitioners that Burt's money would be like a pit of rotting potatoes and that he would never gain possession of the land (Binney, 2001, 2010). However, this prediction was not to come true. Burt's actions included using the signatures of minors, acquiring shares from those who did not own them, purchasing without witnesses, purchasing the shares of deceased persons, getting people drunk and then getting them to sign over their shares, and providing guns and gunpowder (Paul, 1995).

The judicial inquiry ascertained that the Native Land Court's partition order was based on proof given by Māori who were manipulated by Burt (Binney, 2001, 2010; Paul, 1995). The inquiry was then referred to Judge Wilson who, in 1889, after a lengthy investigation, found that 'Burt behaved fairly toward the natives in the matter of this purchase until they turned against him and placed themselves under the guidance of Te Kooti' (Paul, 1995, p. 29). This investigation included claims and counterclaims between Patuheuheu and their leaders, Wi Patene and Mēhaka Tokopounamu, Ngāti Manawa's leaders and Harry Burt.

Patuheuheu were unequivocally disadvantaged and impoverished by the court disputes surrounding Te Houhi. The courts eventually recognised that the people of Te 
Houhi had been severely wronged, but were unwilling to help (Binney, 2001). The judge stated:

I regret the hardship to the defendants. That they have suffered a grievous wrong is, in my opinion, plain. It is doubly hard that this wrong should have resulted from a miscarriage, which certainly ought to have been avoided, in the very Court which was specially charged with the duty of protecting them in such matters. The plaintiff is, of course, blameless in the matter. (Binney, 2001, p. 151)

The plaintiff was Margaret Beale, who had acquired title from Margaret Burt, wife of Harry Burt, knowing full well about the fraudulent nature of the original purchase (see Binney, 2001, 2009a, 2010).

The land on which Te Houhi was located eventually came to be owned by James Grant, in part because of his own manipulations (Binney, 2001, 2010). The people had been advised in 1890 by their lawyer, Henry Howorth, that maintaining peaceful and continued occupation of their land would be enough to ensure ownership; the people would only leave if forced (Binney, 2009a). However, when Grant took official ownership of the land in February 1907, he made it difficult for the people to stay by destroying their cultivations. He eventually evicted the people, assisted by the police, in the winter of 1907 (Binney, 2001, 2009a, 2007c, 2010; Boast, 2002; Wylie, 1908, cited in Wouden, 1980). Some local narratives maintain that Patuheuheu were evicted at gunpoint. Boast (2002) stated:

The mean-spirited and vindictive James Grant, a local landholder who was apparently driving the entire process, ensured that the eviction process was as complete and demeaning as possible, even preventing them from taking their school house and wharenui from the land. (p. 156)

Figure 8 shows some of the individuals involved in this land dispute, including John A. Beale (solicitor for Margaret Beale), the sheriff, R. G. Thomas, and bailiffs serving evictions notices at Te Houhi, December 1905. The local constable Andy Grant is fourth from left, at the rear, with a pipe in his mouth. Beale, wearing a cap, is in the centre. Sergeant William Phair is in front of Grant (Binney, 2010, p. 208). 


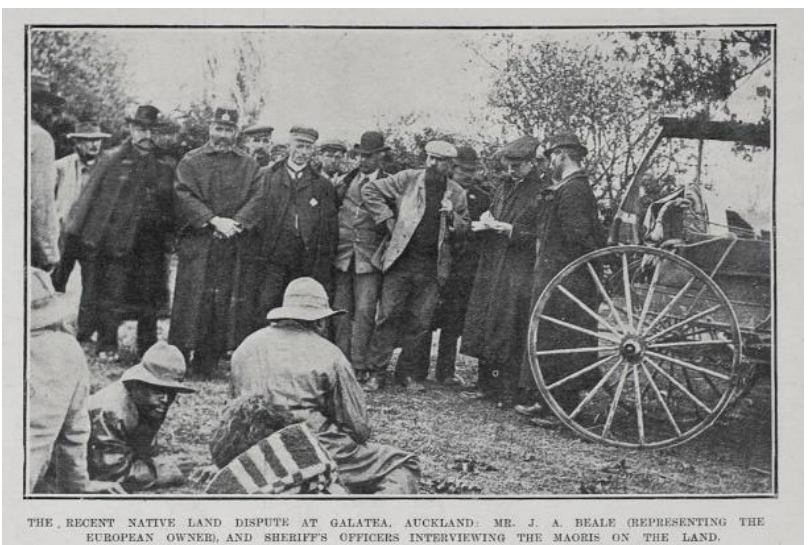

Figure 5. Native land dispute at Galatea(Auckland Weekly News, 1906).

As well as the school house and wharenui, Patuheuheu had to leave behind their church and the sacred bones of their dead (Binney, 2001, 2009a, 2010). Paul (1995) claimed that the ancestral remains were uplifted and relocated around the time of Patuheuheu's eviction, while Binney $(2001,2009 a, 2010)$ maintained that Patuheuheu did not return to Te Houhi to collect their ancestral bones until 1924. Some accounts claimed that the government purchased the wharenui from Grant for $£ 140$ in 1908 (Binney, 2001, 2009a, 2010; Boast, 2002; Paul, 1995).

Despite the different stories, the wharenui was clearly removed and the people relocated gradually. Assistance was refused, except for a £40 grant from the government to purchase food for those who had none (Binney, 2001, 2009a, 2010). According to Binney (2001, 2009a, 2010), the wharenui would have been moved by wagon; however, local oral accounts claim that the wharenui was transported, perhaps in parts, via the Rangitaiki River. The wharenui re-opened at Waiōhau on 28 July 1909 (Binney, 2001, 2009a, 2010; Paul, 1995).

Because of the land loss suffered by Patuheuheu, Te Kooti uttered a prophecy. Te Umutaoroa is a prophetic, utopian discourse that promised Patuheuheu the return of their lost lands and resources and, according to some 
narratives, the discovery or generation of other resources, such as diamonds, gold, oil and minerals (Binney, 2001).

According to both Hieke Tupe (Binney, 2001, 2007c, 2009a, 2010) and Robert (Boy) Biddle (Binney, 2001, 2007c, 2009a, 2010), Te Kooti had his vision in 1886 and named the land on which this event took place Te Umutaoroa. Robert Biddle stated:

Up where the Aniwhenua dam is, now, it used to be dry land before ... Te Kooti was there, he slept at this particular pā [Te Houhi], and where he did sleep, he said to them in the morning, 'I had a dream last night: the valley of the Rangitaiki here was just dense fog'. He said, 'I couldn't see through this fog, so the place where I slept, it will be known as Te Umutaoroa'. That's a hāngī-it would be perpetually in that form until this person came and uncovered it. (Binney, 2009a, p. 494)

As in other parts of the Pacific, Māori in Aotearoa New Zealand traditionally cooked food using an umu, or earth oven. A pit is dug in the earth, in which a fire is burned for several hours to heat stones. Once these stones are hot, food in woven baskets is placed on top and covered in leaves and then soil. After the required cooking time, the soil and leaves are removed, and the food is ready to be served. 'Te Umutaoroa' refers to this process of cooking in a metaphorical way and, as the name suggests, this particular umu requires a long cooking time (tao roa).

Within this hāngī (earth oven) pit, it is said that Te Kooti placed eight mauri stones to be uncovered by a future leader-his child or son-to restore all that the people of Te Houhi had lost (Binney, 2001, 2007c, 2009a, 2010). Hieke Tupe gave the following meanings of the mauri of $\mathrm{Te}$ Umutaoroa:

Te mauri atua: the essence of spirituality; the belief in God

Te mauri whenua: the life force of the land

Te mauri tangata: the life force of the people

Te mauri whakapono: the power of belief, or faith people

Te mauri whakaora i nga iwi: the power to heal the

Te mauri hohonu: the mauri [life force] of hidden wealth-minerals, gold, diamonds and oil (perhaps), which lie underground

Te mauri arai atu i nga pakanga: the power to return war from this land to other countries 
Te mauri whakahoki i nga iwi: the power to return people to their land. (Binney, 2001, p. 158)

The uncovering of these eight stones guarantees the people of Te Houhi spiritual and physical renewal, regeneration, reuniting of people and land, and economic security (Binney, 2001, 2009a, 2010). Te Kooti's prophecy promises Patuheuheu the 'cooked sustenance' of life and salvation (Binney, 2001, 2007c, 2009a, 2010). In 1892, Te Kooti clarified his vision further:

Te kupu ki te Umutaoroa-Te Houhi

Ka taona e ahau tenei hāngi ma taku tamaiti e hura

Tenei mea te hāngi, ko nga kai o roto hei ora mo te tangata

The word concerning Te Umutaoroa-Te Houhi

I am preparing this hāngī (earth oven) for my child to unearth.

The food inside this hāngī will be for the salvation of the people. (Binney, 2009a, p. 494)

To this day, Te Umutaoroa remains unfulfilled. However, it is a discourse in a constant state of flux, shifting from the past to the present, subjected to discursive modification, shaping the prophecy for the contexts in which it is used to inspire and give hope. According to Binney (2007c):

Te Umutaoroa has become an unfulfilled questnarrative. It is unfulfilled because the land is lost; indeed, it is now drowned beneath the waters of a hydro-electric dam, built in 1980. Little islands dot the lake where Te Umutaoroa once was. Once again new meanings are being wrought from this changed landscape. (p. 154)

The story of Te Umutaoroa applies a prophecy of hope and redemption as a healing balm for the loss of Te Houhi. Patuheuheu, Ngāti Haka, Ngāti Whare and Ngāti Manawa are intimately connected through this history. In both Patuheuheu and Ngāti Whare, Ringatū is a major denomination. Though Ringatū is not a prominent faith in Murupara-the home of Ngāti Manawa-there are connections. It was explained to me once that the light blue painted edges of the tukutuku (lattice-work) panels of the original wharenui at Rangitahi marae, Apa-HāpaiTaketake, which was destroyed by fire and rebuilt, represented the Ringatū faith. In the picture below of Tūwhare wharenui, taken around 1905 by Thomas Pringle (see Figure 9), the doorway has a painted lintel featuring 
painted figures. The one to the far right, described as painted in a checkered suit, is claimed to be Te Kooti.

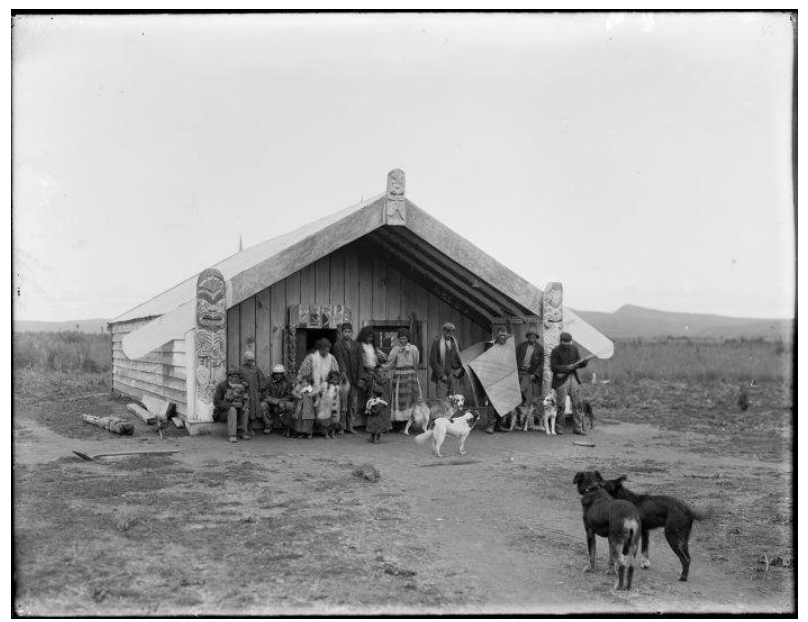

Figure 6. Group outside a meeting house at Rangitahi pā, Murupara(Pringle, ca. 1905).

I am connected to Rangitahi marae and Ngāti Hui through my descent from Peraniko Tahawai, the paramount chief of Ngāti Manawa from 1864 until his death in 1877 (Binney, 2009a). According to Crosby (2004), Peraniko was a soldier in Gilbert Mair's pursuit of Te Kooti from 1869 to 1872 .

Gilbert Mair is best known as a soldier, but he was also a land surveyor, land purchase agent, te reo Māori interpreter and tikanga expert, unrivalled among Pākehā, and one of the very few Pākehā to lead a Māori fighting unit (Crosby, 2004). In Mair's (1923) account, Reminiscences and Maori Stories, he speaks of his friendship with Peraniko. After Mair (1923) left the Bay of Plenty area, he received word of Peraniko's death, but was unable to travel to Galatea for the tangihanga. Two years after Peraniko's death, Mair returned to Galatea and recorded the following account of his experience:

Lifting my eyes to the front of the carved house, imagine my feelings on being confronted with my deceased 
friend Peraniko, who had been exhumed from the grave wherein he had lain for two years. The body had been carefully washed; his jet-black hair, which had grown very long, was oiled and ornamented with rare plumes of the huia and white crane. He was seated on a high structure plentifully adorned with choice mats, while his cold hand still grasped the family talisman, a greenstone mere. Death had wrought no change, nor was there the slightest odour. He had always been remarkable during life for his high complexion, rivalling that of a half-caste, and it still appeared perfectly natural, except for slight dark rings under the eyes, which were closed as though asleep. At his feet were the faithful widow bowed in an agony of grief, and with her were the children. Hatless and with bowed head I stood for nearly three hours, deeply moved by the affecting strains of the tangi. (pp. 65-66)

Peraniko's union with his second wife Mamae produced at least two children that I am aware of. Mair (1923) stated that 'two of their children had been baptized Te Mea [a transliteration for Mair] and Riripeti (Elizabeth) after my parents' (p. 64). Riripeti married a Catholic Irishman and from this union came Rangimaewa. Rangimaewa married Maki Nātana and from this union came my great-grandfather, Hāpurona.

\section{Dramatic Genuflections and Sanctus Bells: Ngāti Manawa, the Fitzgeralds and Catholicism}

Following the Norman conquest of England in 1066, Norman expansionism reshaped the political landscape in south Wales through the late 11th and 12th centuries (Johns, 2013). Princess Nest, daughter of Rhys ap Tewdwr, King of Deheubarth, married Gerald of Windsor around 1097 (Johns, 2013). The Fitzgerald family-represented by St Patrick's saltire-are the progeny of Nest and Gerald (Johns, 2013). The Fitzgerald dynasty gained power in Ireland through Gerald's grandsons by conquest of large tracks of Irish territory (Johns, 2013). The phrase 'more Irish than the Irish themselves' is used in Irish historiography to denote the Gaelicisation that occurred in late medieval Norman Ireland (MacLysaght, 2006). The Irish Norman lords who had settled in Ireland formed septs and clans based on the established indigenous Gaelic design (MacLysaght, 2006; Palmer, 2001). Over many generations, they had become Gaelicised (Gibson, 2012). 
Ireland was ruled by the English from the 12th century and those Irish settlers who immigrated to Aotearoa New Zealand in the 19th and early 20th centuries were British citizens (Phillips, 2015). There was a deep resentment on the part of Irish Catholic peasants in Ireland towards the Anglo-Irish Protestants who took their land, maintained power as landlords and supported English rule; by the 1860 s, half of Ireland was in the hands of a mere 750 people, most of whom were Protestants (Phillips, 2015). These conditions were worsened because of land division by inheritance, the transfer of land used for crops into sheep and cattle farms, reduced work opportunities, and industrialisation, which eliminated the supplementary incomes gained from domestic spinning and weaving (Phillips, 2015). In the 1840s and early 1850s, a devastating potato famine claimed the lives of over one million people (Ó Gráda, 1989; Phillips, 2015).

During the 1800 s, particularly following the famine, the Irish left Ireland in search of better lives; from 1850 to the 1920s, the population of Ireland was halved as over one million Irish went to England or Scotland and over four million travelled to America and, to a far lesser extent, Australasia (Phillips, 2015). The New Zealand Company offered assisted passages for settlement, but Irish Catholic peasants were not desirable and less than two per cent of the company's settlers were born in Ireland (Phillips, 2015). Anglo-Irish settlers were part of a privileged group of Protestants, an Anglican elite, who believed their positions back in Ireland were severely compromised by Catholic emancipation and Irish nationalism (Phillips, 2015).

Bishop Pomapallier from France and the Society of Mary brought Roman Catholicism to Aotearoa New Zealand. However, as most Catholics in the 1860 s were Irish, Catholicism increased their Irishness as 'a major vehicle for expressing Irish heritage' (Phillips, 2015, n.p.). The appointments of Bishop Patrick Moran in 1869 and Bishop Thomas Croke in 1870 drew the Catholic Church in Aotearoa New Zealand closer to the 'Catholic Empire' of Ireland's Cardinal Paul Cullen (Phillips, 2015; Simmons, 1978) who, as an Archbishop, significantly influenced the increase of Irish Catholic religiosity (Lineham, 2017). For Bishop Moran, Irish identity and Catholicism were one and the same; Catholicism was indeed central to Irish life and identity in Aotearoa New Zealand (Phillips, 2015). Bishop 
Pompallier's approach was to visit as many Māori communities as possible and he was admired by Māori for his resolve (Simmons, 1978). A mission was established in Tauranga in 1840 and by 1844 there were 12 stations, two of which were established at Whakatāne and Rotorua (Simmons, 1978), the closest stations to Murupara.

While a full history of the Māori Catholic missions in the Bay of Plenty is well beyond the scope of this article, I am confident that Catholicism made its way to Murupara from another location in the Bay of Plenty. My third great grandfather, Edward (Ted) Fitzgerald, who died in 1947 and who is buried at Waiōhau, was part of the first wave of Pākehā to come to Murupara and was certainly Catholic. Catholicism, through whakapapa and whakapono, forms part of my religious identity and experience.

Nan described her great-grandfather, Edward Fitzgerald, as bedridden and frightening. She said he spoke with a strong accent and rang a bell when he wanted something, but that when she would go in to see what he wanted, he would try to hit her with his cane! His origins and the precise details of how he came to live in Aotearoa New Zealand, and specifically in Murupara, are at this point unknown to me. My great-great-grandmother and daughter of Edward (Ted) Fitzgerald, Rangimaewa, was a strict Catholic. Her discipline around fasting and praying the Rosary are testament to the highly disciplined faith typical of the austere Irish Catholic religiosity shaped by Cardinal Cullen in the 19th century.

One of my earliest 'Catholic' memories occurred in the mid- to late 1980s, watching Friedkin's (1973) film The Exorcist at home on Miro Drive, Murupara, late one Sunday night. Linda Blair describes the film as a 'theological thriller' and William Friedkin calls it a 'story about the mystery of faith' (Bouzereau, 2010, n.p.). I sat front and centre on the floor, in full view of the screen, reminiscent of Carol Anne from Hooper's (1982) Poltergeist. My cousins sat back on the couch, huddled together as a deluge of horrifying 1970s special effects assaulted their minds with the spinning head and projectile vomit. Kline (2018) explained that after watching the film some people experienced psychological trauma.

Watching scenes of Fathers Merrin and Karras in full combat with the demon-possessed girl, I was more fascinated by the priestly garb-cassock, surplice and 
purple stole-the intense prayers and the fanatical sprinkling of holy water, rather than the terrifying contortions of Regan's ragged body. Certainly, an obsession with crucifixes and Christian iconography would become part of my ongoing theological explorations in life.

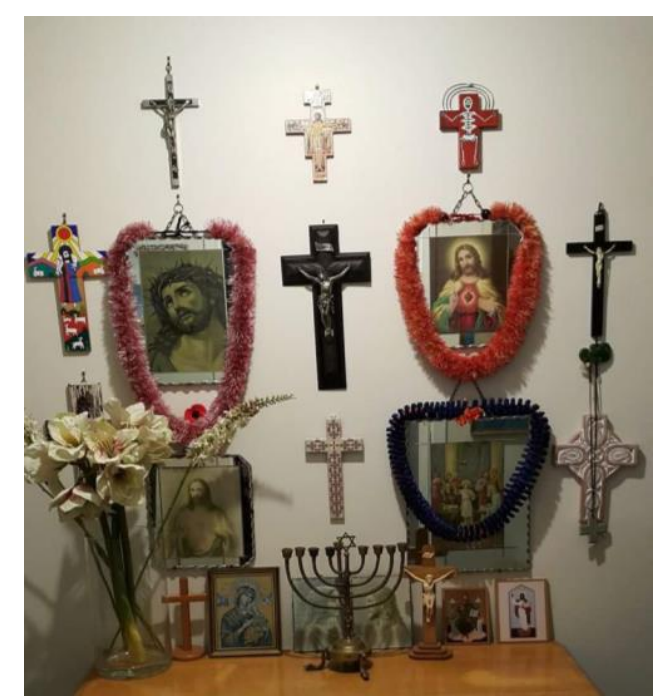

Figure 7. A small section of my collection of religious iconography.

On Pohutukawa Drive, Murupara, came another 'Catholic' experience. For some reason, I decided that I should strip the leaves from a council-planted shrub near the alleyway that led back to Miro Drive. A nun discovered me in action and stopped me in my tracks. She told me to pick up all the leaves, bury them and ask God's forgiveness for attempting to destroy one of his creations. Unlike Sister Mary Stigmata from the Blues Brothers, this nun was not scary, and she certainly did not float. However, she did teach me that all living things should be respected, even a seemingly insignificant kerbside bush.

At Sacred Heart Catholic Church in Murupara, I witnessed my first Mass. I had been exposed to Catholic practices through television and film and, while I was not 
Catholic and had never experienced Catholicism as such, it was simply a case, as St Ambrose of Milan noted centuries ago, of doing as the Romans do (Speake, 2015). As I entered the church, I dipped my fingers into the font and crossed myself. Before taking my seat, I genuflected and crossed myself with great spectacle. Cardinal James R. Knox (1980) said that the 'venerable act of genuflecting before the Blessed Sacrament, whether enclosed in the tabernacle or publicly exposed' is a 'sign of adoration' and that genuflection must 'be neither hurried nor careless' so that the 'heart may bow before God in profound reverence' (p. 38). My genuflection, while not 'hurried nor careless', was certainly theatrical. In Karaititanga: Some reflections on my Christology, I stated:

I always nod in the direction of a cross. I solemnly bow toward an altar. And I genuflect with both sincerity and drama when in the presence of a tabernacle. I attribute this respect toward crosses, crucifixes, altars and tabernacles or aumbries to both my Katorika [Catholic] and Mihinare [Anglican] whakapapa. My theology of the Eucharist is that it is the spiritual body and blood of Jesus and that I should venerate it. (Rangiwai, 2018b, p. 601)

The parishioners were mostly Māori. The older women wore black lace mantilla or scarves over their heads, which did not seem unusual to me. It was widespread Catholic practice for women to cover their heads in this way based on 1 Corinthians 11:2-16 (KJV) and canon law that up until 1983 required women to cover their heads 'especially when they approach the table of the Lord' (Edwards, 2001, p. 427). Older Māori women in the 1980s in Murupara often wore scarves over their heads. At tangihanga, in particular, their heads were covered with long black veils. Significantly, many of these women were of the Ngāti Hui hapū of Ngāti Manawa, which is comprised of many Catholic whānau.

The priest was Pākehā. The smell of incense was intoxicating and the clinking of the thurible-'a metal vessel which holds burning charcoal embers and incense and is swung from, typically, three chains' (Herrera, 2011, p. 4)-was rhythmic. It was swung in sets of three as the priest sanctified the altar with fragrant smoke, communicating a 'sense of mystery and awe' (Herrera, 2011 , p. 6). When the priest elevated the host, the sound of the Sanctus bells-'part of the celebration of the Holy 
Sacrifice of the Mass' for more than 800 years (Herrera, 2004 , p. 1) - sharpened my focus as I gazed on the miracle of transubstantiation happening before my eyes. Herrera (2004) stated that Sanctus bells 'help focus the faithful's attention to the miracle taking place on the altar' (p. 3).

The theatre of Mass laid the foundations for how I would come to relate to God. When bread and wine become to me the body and blood of Christ, I find a sense of peace and belonging, oneness and unity with humanity and a cosmic connection to the Divine, for here, in this holy meal, one consumes the sacred blood and body of God incarnate. One cannot avoid the vampiristic and cannibalistic imagery that this act conjures: of consuming Christ's flesh and drinking his blood, of feasting upon the wounded Christ lain upon the altar.

I noticed, even as a young person, that after handling the host, the priest held his thumbs and forefingers together before and after the consecration. This was to ensure, I later discovered, that any remnants of the hostpre- and post-transubstantiation-were not lost and, consequently, defiled-and to ensure that the particles could be rinsed off the fingers with water at the end of the ceremony and consumed by the priest (Cooper, 2010). Reflecting, I wrote:

The priest holds his fingers

Together

After handling the wafer

For fear of dropping

Jesus particles on the floor

Rinse those pinchy

Pincer-like fingertips

with water and swish

it round the blood-stained

chalice

His portly face goes bright red

when he swallows deeply

the remainder of Christ's blood

floaty bits 'n' all. (Rangiwai, 2018b, p. 602)

The Christian Brothers were in Rotorua from 1962 and departed for Murupara in 1989 (Cameron \& Forbes, n.d.). One of the brothers thought that I should become an altar boy. Unfortunately, I was not only not Catholic, I had not been baptised at all. My parents were not religious, and they certainly had no desire to force their children to follow 
any particular creed or faith. I remain absolutely fascinated by Catholicism to this day. While I am a practising Anglican-the apparent via media-these days, I do prefer the more Catholic end of the liturgical spectrum and I may be found occasionally praying the Rosary or participating in a Catholic Mass.

Although Nan's siblings were baptised Ringatū or Catholic, with one Presbyterian 'in the mix', one of her siblings who had originally been baptised Catholic instead went down a Pentecostal pathway of faith. This weaves Pentecostalism into the whakapapa. As already mentioned, we called Pentecostals pakipaki. Unlike the Catholics, pakipaki songs were catchy and their sermons energetic. A belief in the inerrancy and literality of the Bible, combined with language like 'crusades'-Pentecostal revivals (Gordon \& Hancock, 2005)—seemed to give them a militant edge. Without the 'smells and bells' and 'frocks' of Catholicism, they were more contemporary; and with a focus on a bare cross and a risen Christ-as opposed to one sacrificed over and over on the altar-their theology seemed radically different. As I am almost always interested in that which is different, I investigated Pentecostalism for myself.

\section{Pentecostal Experiences}

Pentecostalism in Aotearoa New Zealand is generally associated with the evangelical work of Smith Wigglesworth in the 1920s (Moetara, 2012). Pentecostalism has grown rapidly among indigenous people worldwide and Moetara (2012) noted three reasons for this. First, 'Pentecostalism in the majority of the world has been accepting and supportive of indigenous culture expression and practice' (Moetara, 2012, p. 75). Second, 'Pentecostal churches have established order, security and hope for those dislocated through rural-urban migration' (Moetara, 2012, p. 75). Third, 'Pentecostal belief in the spiritual world resonates with indigenous beliefs' (Moetara, 2012, p. 76). The success of Pentecostalism among Māori, Moetara (2012) argued, has not been as successful as one might imagine considering the international indigenous reception of Pentecostalism experienced in other parts of the world. Indeed, the rejection of Māori culture and customs has been Pentecostalism's greatest obstacle to Māori participation (Moetara, 2012). 
In the 1990s, I attended a Pentecostal church. We raised our hearts and voices, we clapped our hands and stomped our feet to 'Make joyful noise unto the Lord' (Psalm 100: $1 \mathrm{KJV}$ ). There was little tolerance for things Māori, which were often openly dismissed as ungodly. There was no te reo Māori used in any church service. Kim Workman spoke of an experience witnessing a well-known evangelist 'pray the Māori spirit out of people' (cited in Moetara, 2012, p. 78). Workman also communicated an experience in which a Pentecostal church identified socalled satanic areas to be 'prayed against', which involved urupā (burial grounds), marae and whakairo (carvings) (Moetara, 2012, p. 78).

The Pentecostal church I attended was so fundamentalist in their views that talking, adolescent, sword-wielding turtles-and most other cartoons on television at that time-were deemed unwatchable and satanic. Turner Broadcasting System's cartoon Captain Planet and the Planeteers is another such example. It featured Gaia, the 'spirit of the earth', who, outraged at the 'desecration of the earth', creates and gifts of 'five magic rings to five children from different continents' (Muir, 1993, p. 5). Each of the magical rings 'gives the bearer power over an element-Earth, Wind, Water, Fire, and the fifth power of Heart' (Muir, 1993, p. 3). When these powers are combined, 'Captain Planet emerges to save the day' (Muir, 1993, p. 3). Gaia, of course, is the primal Greek goddess who personified the Earth while her son and husband, Uranus, anthropomorphised the sky (Woodard, 2007). If magical rings were not enough to force the Pentecostal gaze away from the television, then this was certainly achieved through Greek mythology.

In our own individually aspirated glossolalia, we spoke in tongues and asked that God stop Saddam Hussein. During my first experience with glossolalia, I was instructed to repeat 'peanut butter' until I found my own way of expressing myself. Glossolalia simply means to 'talk language' and is characterised by an absence of recognisable words or semantic content-except biblical words and phrases-accelerated speech, altered accents and melody and an excessive number of small phonemes (Chouiter \& Annoni, 2018).

For the faithful, glossolalia 'manifests on the tongues of believers as they encounter, in the fullness, the 
immanence, power, and presence of their God in a moment of cognitive surrender' and 'brings about a suspended moment of encounter with the holy' (Willis, 2018, p. 219). There are supposedly some physical and psychological benefits from glossolalia. Lynn (2009) claimed that speaking in tongues lowers a person's biological stress response to daily stressors, while Torr (2017) argued that lamenting in glossolalia allows a person to express the deeply unsayable and provides catharsis.

The sound of a church full of people shouting, mumbling, moaning, shrieking, hissing and grunting in unintelligible 'languages' felt both strange and exciting. Once I had established a post-'peanut butter' vernacular of my own, my attempt at speaking tongues sounded like some sort of Polynesian language with the rhythm and tempo of a drum roll. That my 'language' sounded vaguely Māori is not surprising because Chouiter and Annoni (2018) observed that glossolalia resembles the language(s) of the speaker. While I am not a fluent speaker of te reo Māori, I understand some of the Tūhoe dialect that was spoken by Nan, her siblings and her parents.

Pakipaki is a Māori term meaning 'to clap'. It is used among my people to describe those from a 'happy clappy' or Pentecostal church, which included some of my relatives. The 'happy clappy' is really a Christian caricature (Jones \& Webster, 2006) or cliché (Ransford \& Crawford, 2018), much like the 'evangelical stereotype' Ned Flanders 'whose actions are simultaneously mocked and praised in a way that denigrates evangelicals ... while supporting individual acts of piety and Christian morality' (Feltmate, 2013, pp. 222-223). The term is also used to describe 'musical styles in a lighter, populist genre' (Webber \& Freke, 2006, p. 859) and, indeed, my relatives played the guitar and sang beautifully in this style. This music was definitely more modern than Ringatū chants or the te reo Māori version of the Roman Catholic Litany of the Dead. At tangihanga in Waiōhau, we would sing a pakipaki song based on the text from the gospel of John, and which is still sung today at our marae:

Let not your heart be troubled; ye believe in God, believe also in me.

In my Father's house are many mansions: if it were not so, I would have told you. I go to prepare a place for you. 
And if I go and prepare a place for you, I will come again, and receive you unto myself; that where I am, there ye may be also. (John 14:1-3 KJV)

While this song was sung, the guitar chords and emotional singing blended with the sobbing and gentle wailing of the women as whānau wept around the tūpāpaku (corpse), devastated that a loved one had passed on, but with hope that Jesus would prepare a place for them in heaven.

Gundry (1969) presented two meanings for Jesus's words to his disciples. The first meaning is that Jesus says he will go to the cross to die, prepare spiritual dwellings in his Father's house, return to his disciples immediately following his resurrection and send his spirit to 'minister his continuing presence until he comes to receive those who are already in him so that they may be with him eternally' (Gundry, 1969, p. 72). The second meaning is that Jesus says he will go to his Father's house in heaven, prepare homes for his believers and return and take his believers 'to be with him in heaven forever since they have already come to be in him by faith' (Gundry, 1969, p. 72). However, Gundry (1969) also stated that 'the two meanings merge' (p. 72).

Jesus's promise that he will go and prepare mansions in heaven for his followers is a comforting idea. Having a mansion of my own, considering that I grew up in a small town in a small home, is a highly appealing image. However, Mormon theology takes the afterlife to the next level. The belief is that, through righteousness and sacraments-which Mormons refer to as 'ordinances'-one may attain godhood in the highest of all heavens, the celestial kingdom. I would describe this theology, rather irreverently, as 'heaven on steroids!' Eternity in heaven is great, but becoming a god and the endless potential conjured up by that notion is both mindboggling and exciting. While Mormon theology may seem a bit 'farfetched', when compared to human religious beliefs generally, it is no more untenable than the separation of Ranginui and Papatūānuku, or transubstantiation, might be to an 'outsider'. 


\section{Suits, Cycles and The Book of Mormon musical: Experiences and Reflections on Mormon Theology}

My association with the Mormon Church-known more formally as The Church of Jesus Christ of Latter-Day Saints-was short-lived: in 1996, I was baptised in Murupara; in 1997, I attended Church College in Hamilton; in 2001, I engaged in mission for the Mormon Church; and, in 2003, I was excommunicated for a serious breach of church rules. The following explores my thoughts regarding The Book of Mormon, a musical written by Trey Parker, Matt Stone and Robert Lopez, in the light of my own brief Mormon experiences. A more detailed exploration of Māori responses to Mormonism can be found in Robert Joseph's (2012) work.

The Book of Mormon premiered in 2011 and won nine Tony Awards in its opening year (Hoxworth, 2017). It toured twice in North America, debuted in the West End in 2013 and opened in Australia in 2017. It has also maintained success with a continued Broadway presence. I had the chance to enjoy The Book of Mormon in the Lyric Theatre, Sydney, in 2018. I remember sitting in anticipation, admiring the proscenium, unsure of what to expect. The Hill Cumorah prologue was familiar-it reminded me of the Temple Pageant that I saw at the Hamilton New Zealand Temple in the late 1980s, when I was non-Mormon. The prologue neatly set the scene, introducing the Mormon Church as the fastest growing religion today! A church that even now sends missionaries out ... all over the world' (Parker, Lopez \& Stone, 2011, p. 1). As the next scene began-Elder Kevin Price, a young, dashing Mormon missionary in a white shirt and black tie, walks up with a big smile on his face, holding the Book of Mormon. He pantomimes ringing a doorbell and we hear 'Ding Dong!' (Parker et al., 2011, p. 1)-I was reminded of my own experiences.

In 2002, entering the Missionary Training Centre (MTC) in Hamilton, Aotearoa New Zealand was a similar time of spiritual discovery. The trainees there-including me-were filled with zeal and were eager to preach the gospel. The focus of our training at the MTC was how to teach 'the discussions'. According to White (2010), 'the questions of what to teach and how to teach it have led to four sets of formal missionary discussions published by the Church beginning in 1952 and continuing on to 1961, 
1973 and 1986' (p. v). We were trained using the six lessons contained in the Uniform system for teaching the gospel (The Church of Jesus Christ of Latter-Day Saints, 1986).

After training, we were sent our separate ways. We were naïve, but as prepared as possible. One of the areas in which I most enjoyed working was Christchurch (see Figure 11). Knocking on doors was frightening and exciting; when people answered, we stood with smiles on our faces and said something like, 'Hello. We are from The Church of Jesus Christ of Latter-Day Saints and we'd love to share a message with you about eternal life.'

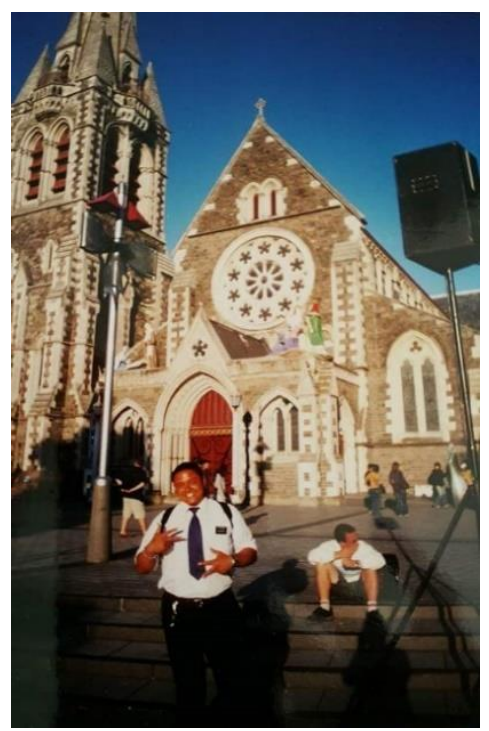

Figure 8. Elder Rangiwai (me!) outside Christchurch Cathedral.

Although intentionally cheesy, the lyrics in 'Hello!', the opening number of The Book of Mormon, captured the essence of our message and resonated with my missionary experience. We were on strangers' doorsteps because we believed, perhaps idealistically, that the message of Mormonism would change their lives. 
On reflection, I think that my experience was one of religious foolishness - a concept articulated by theologian Reinhold Niebuhr. According to Sirvent and Baker (2016):

The foolishness Niebuhr speaks of manifests itself in two principal forms: (1) an unrealistic view of the world and (2) the conviction that one's group possesses unfettered ... access to the divine and is therefore insusceptible to the pride and self-love that plague other religious groups. (p. 44)

Mormons maintain that their religion is the one true faith and that, through its ordinances, a person and their entire family may be exalted to godhood. This unshifting belief fulfils Niebuhr's second parameter for religious foolishness. Likewise, I held an unrealistic view of the world and believed that the gospel would solve the problems of those who accepted it.

While Mormon missionaries are not assigned to permanent companionships, to serve the plot in The Book of Mormon's song, 'Two by Two', Elders Price and Cunningham were assigned as permanent companions and sent to Uganda to find converts on a similarly unrealistic, even foolish, mission. Mission was a personally challenging time during which my faith was tested, and it was faith and social and religious pressures that motivated me to search with my companion for people to teach.

Elder Price, having newly arrived in Uganda, was confused about his mission. The song 'Turn it Off' indicated that Mormons must 'switch off' sinful thoughts. The elders sang about how easy it is during harrowing times to simply 'turn it off!'. According to Elder McKinley:

Turn 'em off

Like a light switch,

Just go 'click' 25)

It's a cool little Mormon trick. (Parker et al., 2011, p.

Elder McKinley's 'sins' were his homosexual thoughts. Elder Price assured him that having such thoughts was acceptable provided he did not act on them. In my experience, as a former Mormon who is also gay, this notion is consistent with Mormon thinking as, according to the Church, 'sexual relations ... between people of the same sex violate one of our Father in Heaven's most important laws' (The Church of Jesus Christ of Latter-Day Saints, 2018 b, n.p.). Humming a hymn or saying a silent prayer- 
in a sense, 'turning it off'-are commonly espoused strategies intended to refocus one's thoughts away from temptation.

In 'I Believe' (Parker et al., 2011, pp. 68-71), Elder Price sang: 'you cannot just believe part-way/you have to believe in it all' (Parker et al., 2011, p. 68). For Newhouse (2016), this represented the real message of The Book of Mormon: 'on the one hand, we are meant to celebrate Price finally living out the strict demands of his faith; on the other, those tenets ... sound bizarre enough to merit honest laughter from the (mostly) non-Mormon audience' (p. 79). This notion of simply believing regardless of how strange beliefs may appear is the tricky rhetorical line that The Book of Mormon straddles ... encouraging us to laugh at beliefs, practices, and attitudes that seem at best naïve and at worst absurd' (Newhouse, 2016, p. 79).

For missionaries like Price, adherence to Mormon beliefs has dramatic significance. Mormonism posits that worthy members of the Church may become godlikeessentially, gods themselves. It is implied in Mormon theology that, if God has created 'worlds without number', then, as gods, worthy Mormons might do the same. 'And worlds without number have I created; and I also created them for mine own purpose' (Moses 1:33 KJV, The Pearl of Great Price; see Figure 12). However, the specifics of godhood remain unclear. Mormon temple rituals provide members of the Church with certain assurances regarding the potential of godhood in the life to come (see Buerger, 1994, 1987). In an official statement, the Church asserted:

Latter-Day Saints' doctrine of exaltation is often ... reduced in media to a cartoonish image of people receiving their own planets ... while few Latter-Day Saints would identify with caricatures of having their own planet, most would agree that the awe inspired by creation hints at our creative potential in the eternities. (The Church of Jesus Christ of Latter-Day Saints, 2014a, n.p.)

In response to this statement, Wiener-Bronner (2014) stated: 'Mormons don't believe in heaven as planet per se, but they also don't not believe in it' (n.p.). 


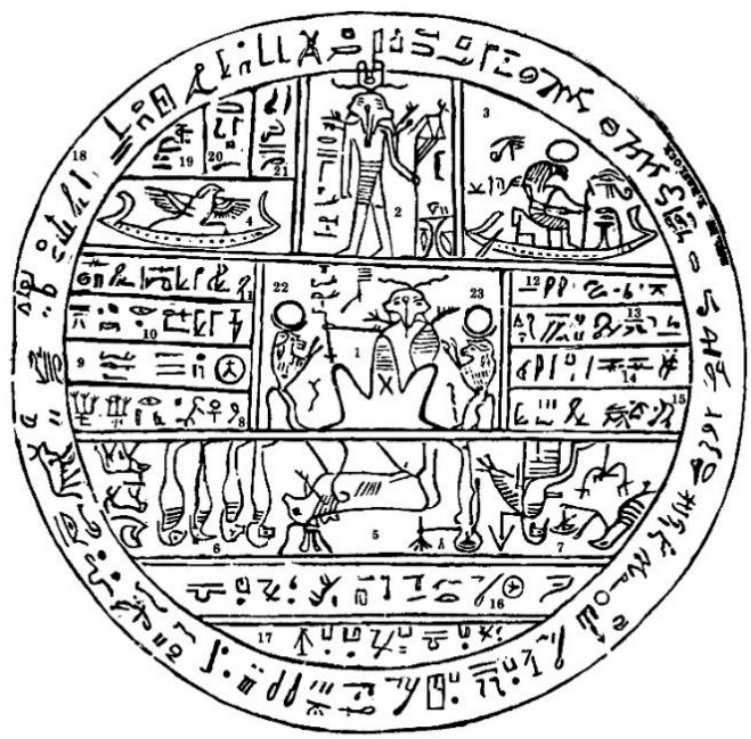

Figure 9. A facsimile from the 'Book of Abraham, No. 2', The Pearl of Great Price.

Mormon theology also insists that God is glorified flesh and bone. Unlike in Orthodox Christianity, Jesus is believed to be separate from God, not God's human incarnation. Paulsen (1995) referred to this as 'divine embodiment', stating that 'the doctrine that God the Father and God the Son are embodied persons, humanlike in form, has rich implications for both philosophical anthropology and theology, and it is one of the most distinctive teachings of the Restoration' (p. 7). I agree that while the doctrine of the Church leaves room for interpretation regarding the afterlife, Mormon conceptualisations of exaltation do tend to include godhood and the creation of worlds.

Another lyric in 'I Believe' claimed that God lives on his own planet called Kolob, that Jesus also has his own planet and that the Garden of Eden was originally located in Jackson County, Missouri (Parker et al., 2011). Richard Bushman, Professor of Mormon studies, stated: 'Mormon theology differs radically from conventional Christianity in 
locating God in time and space. He is not outside creation as traditionally believed. He is part of the physical universe' (cited in Kernis, 2011, n.p.).

The Mormon theology of Kolob intrigued me, despite it being mentioned only a few times in the 'Book of Abraham' (part of the official scriptural canon). Abraham refers to Kolob as follows:

3 And the Lord said unto me: These are the governing ones; and the name of the great one is Kolob, because it is near unto me, for I am the Lord thy God.

4 Kolob was after the manner of the Lord, according to its times and seasons in the revolutions thereof; that one revolution was a day unto the Lord, after his manner of reckoning, it being one thousand years. (Abraham 3:3-4 KJV, The Pearl of Great Price)

Kolob seems to have captured the imaginations of Mormons (and non-Mormons, as is the case with The Book of Mormon musical) despite being mentioned sparingly in the 'Book of Abraham'. Kolob is the subject matter of one of my favourite pieces of Mormon music, 'Hymn 284', in Hymns of The Church of Jesus Christ of Latter-Day Saints, which draws inspiration from Abraham 3:1-4, 9 and Moses 1:3-4, 33-39 (KJV) and which asks:

If you could hie to Kolob

In the twinkling of an eye,

And then continue onward

With that same speed to fly,

Do you think that you could ever,

Through all eternity,

Find out the generation

Where Gods began to be? (The Church of Jesus Christ of Latter-Day Saints, 1985)

I found the origins of the 'Book of Abraham' fascinating. Reportedly, a group of Mormons purchased 'two or more rolls of papyrus' from entrepreneur Michael Chandler (Smith, 1835, p. 596). When Prophet Joseph Smith examined the Egyptian papyri and translated the hieroglyphics, he 'found that one of the rolls contained the writings of Abraham' (Smith, 1835, p. 586). While professional Egyptologists have refuted Smith's work as 'utterly absurd' (Nibley, 1968, p. 172), it is noteworthy that 'Smith never pretended to understand Egyptian, nor that the "Book of Abraham" was a work of his scholarship" (Nibley, 1968, p. 176). The official Church position on the 
matter is that the veracity and value of the 'Book of Abraham' cannot be settled by scholarly debate concerning the book's translation and historicity. The book's status as scripture lies in the eternal truths it teaches and the powerful spirit it conveys' (The Church of Jesus Christ of Latter-Day Saints, 2014b, n.p.).

Regarding the Garden of Eden's location, Van Orden (1994) claimed that 'Prophet Joseph apparently instructed ... that the ancient Garden of Eden was also located in Jackson County'. Further, 'relative to the locale of the site of the Garden of Eden, the Prophet ... learned through revelation that Jackson County was the location of a Zion to be and the New Jerusalem to come' (Van Orden, 1994, n.p.).

'I Believe' also identifies a further point of contention: the position of black people in the Church. Early in my Mormon experience, I was interested in the policy that denied the full blessings of the Church, including priesthood, to those of African descent from the mid-1800s until 1978 (The Church of Jesus Christ of Latter-Day Saints, 2018a). I also familiarised myself with Elder Bruce R. McConkie's (1966) controversial book, Mormon Doctrine. McConkie (1966) claimed:

The negroes are not equal with other races where the receipt of certain spiritual blessings are concerned, particularly the priesthood and the temple blessings that flow therefrom, but this inequality is not of man's origin. It is the Lord's doing. (pp. 526-527)

Mormon Doctrine was never considered official Church doctrine; however, its ideas were absorbed uncritically by some of the membership. I found that many Mormons believed the theories regarding race and priesthood. Many professed the fact that, from a Mormon perspective, access to the priesthood extended from Jews to Gentiles and eventually to everyone else, including black people (being the last to receive it), and that this was part of a divine plan. The Church officially renounced all theories concerning race and priesthood in an official Church statement, originally published in 2013:

The Church disavows the theories advanced in the past that black skin is a sign of divine disfavor or curse, or that it reflects unrighteous actions in a premortal life; that mixed-race marriages are a sin; or that blacks or people of any other race or ethnicity are inferior in any way to 
anyone else. (The Church of Jesus Christ of Latter-Day Saints, 2018a, n.p.)

The gospel arrived with the Anglican cleric Marsden in 1814 , but the Mormons did not arrive in Aotearoa New Zealand until 1881. By the early 20th century, the Mormon Church had gained an expansive following among Māori (Joseph, 2012; Kaa, 2017). Many Māori were attracted to Mormonism because of the importance it placed on genealogy. The Mormons, through their central scriptural text-The Book of Mormon-considered Māori to be part of the Lost Tribes of Israel (Joseph, 2012; Kaa, 2017). For the Mormons, Māori were a very special people. This was a view in opposition to that of the English, which saw Māori as savages. The Mormons lived with Māori: 'we spoke the Maori language, we ate the Maori food, we slept in Maori huts, we slept in Maori beds, we studied Maori traditions' and 'in short as time passed, we began to think like Maori' (Dunford, 1889, cited in Joseph, 2012, p. 45).

In what might be described as a 'clash' of Mormon and Anglican leaders and theologies among the Rongowhakaata - a related and neighbouring tribe to the Ngāti Porou-at Manutuke in 1886, Mormon leader President Stewart was greeted by Bishop Williams with these words: "Where were you when the flesh of man singed on the stones of the oven? You have waited until I have made peace with man and man; then you have come trespassing on my preserves' (cited in Joseph, 2012, p. 52). Relating the work of the Anglicans to that of John the Baptist, President Stewart replied-greatly impressing the Māori observers-You have prepared the way for me .... The flesh of man no longer singed on the stones of the oven. You have translated the Bible into Maori and everything is in readiness for me' (cited in Joseph, 2012, p. 52).

Even though Mormonism began as a church in which Māori language was used and Māori customs were tolerated to some extent (see Barber [1995] for an account of Mormon resistance to tohunga), Mormon universalism in the 1950s and 1960s 'was rooted in the dynamics of the international Latter-day Saint church, where a postwar institutional shift toward business efficiency, procedural correlation and conformity provided a less sympathetic context for indigenous expressions in worship and community' (Barber, 1995, p. 160). Indeed, the use of te 
reo Māori in church services is not generally encouraged and Māori cultural practices, such as the use of karanga (formal call) to ceremonially call a tūpāpaku into a church building, are forbidden (this was my experience in Murupara and Rotorua at least), with the idea being that Māori culture should be replaced by a culture of Christ (see Oaks [2010] for a description of the Mormon notion of the culture of Christ). Conversely, in the Māori Anglican Church, Te Hāhi Mihinare, Māori culture is central.

\section{Reconnecting with my 'Nāti' Roots: Ngāti Porou and Te Hāhi Mihinare}

Following my excommunication from the Mormon Church in 2003, I turned to the Mihinare faith of my Ngāti Porou ancestors and, in so doing, I reconciled my relationship with God. For surely, if a church is embedded in iwi culture, whakapapa and whakapono, they could never reject me. My maternal grandfather, Edward Tapuirikawa Brown, was Ngāti Porou and Anglican. Through him, I am part of Ngāti Porou whakapapa and whakapono. Regarding Christianity in the Ngāti Porou context, Soutar (2000) recounted that the Christian message was introduced by influential members of the tribe' who had been captives of Ngāpuhi, and who 'planted' Christianity 'in their own soil' and adapted it 'to the framework of their own spirituality' (p. 97).

In around 1820, a series of malicious raids by Ngāpuhi took many captives back to the North, leading various hapu from throughout Ngāti Porou to consolidate into two important fortified pā in the Waiapu Valley at Rangitukia and Whakawhitira (Te Runanganui o Ngāti Porou, 2019). In 1833, four rangatira from the WaiapuRangikatia, Rangiwhakatamatama, Te Rukuata and Te Kakamara-arrived, after an extensive and tumultuous journey, in the Bay of Islands (Te Runanganui o Ngāti Porou, 2019). Upon their arrival, their previously captured relatives exclaimed: 'Hikurangi maunga tū noa, Waiapu wai rere noa' [Hikurangi still stands and Waipu still flows] as a way of celebrating their sacred mountain and river back home (Te Runanganui o Ngāti Porou, 2019, n.p.). At Paihia, they were reunited with Piripi Taumata-ā-Kura, a rangatira who had been imprisoned and was taught the scriptures by the missionaries (Te Runanganui o Ngāti Porou, 2019). 
According to Mohi Turei, in late 1833, the boat returned carrying the four rangatira, Taumata-ā-Kura and the missionary William Williams, who was also known as Wiremu Parata. After a short service at Wharekahika, Williams and the other Pākehā returned to the North (Te Runanganui o Ngāti Porou, 2019). On 1 January 1834, Taumata-ā-Kura and his fellow kaiwhakaako (teachers and evangelists) began a religious service at Rangitukia (Te Runanganui o Ngāti Porou, 2019). Mohi Turei described this day as a new beginning, when words about a new God would come to be to be heard by Ngāti Porou: 'Te Atua hou tenei ko Ihu Karaiti te ingoa' [This is a new God, named Jesus Christ] (Te Runanganui o Ngāti Porou, 2019, n.p.).

Taumata-ā-Kura preached from biblical stories spanning the Old and New Testaments, with the message that military and political success would be guaranteed if the iwi worshipped exclusively the One True God, 'Ihowa'; that is, Jehovah (Te Runanganui o Ngati Porou, 2019). In the context of a Ngâti Porou people who had gathered together in fear of their enemies returning, it is easy to see why this message resonated (Te Runanganui o Ngāti Porou, 2019).

Taumata-ā-Kura made another impact at the siege of Te Toka-a-Kuku near Te Kaha, where he demanded that bodies be left alone and not looted after battle (Te Runanganui o Ngāti Porou, 2019). According to Soutar (2000), 'Taumata-a-Kura set the new rules for war. There was to be no cannibalism, no fighting on Sundays, prayers morning and night, care for the wounded and no wanton destruction' (p. 108). These new practices were upheld and Ngāti Porou were successful in their battle (Te Runanganui o Ngāti Porou, 2019). Word spread and, according to Mohi Turei, 'enei kupu a Taumata-a-Kura te timatanga o te ohonga o te whakapono o Ngatiporou' [These words of Taumata-a-Kura were the beginning of the awakening of the faith of Ngāti Porou] (Te Runanganui o Ngāti Porou, 2019 , n.p.).

The story of Taumata-ā-Kura was the basis for a new Ngāti Porou whakapono, emphasising that Ngāti Porou made deliberate choices regarding spirituality for our own purposes (Te Runanganui o Ngāti Porou, 2019). This new spirituality had a deep effect on the iwi, making its way into our mātauranga, or knowledge systems (Te Runanganui o Ngāti Porou, 2019). According to Soutar 
(2000), Taumata-ā-Kura 'laid the foundation for the earnest and pronounced acceptance of Christian teaching among his people' (p. 97). He was 'the man Ngāti Porou considered most responsible for the initial spread of the Gospel along the East Coast' and he was 'regarded as the champion of the Christian Church on the East Coast' (Soutar, 2000, pp. 98-102).

The haka (posture dance) 'Tihei Tāruke' was composed by Mohi Turei in 1910 and was based on an understanding developed over generations regarding the meaning of the arrival of Christianity in the Ngāti Porou context (Te Runanganui o Ngāti Porou, 2019). The haka displays the sense of empowerment Ngāti Porou had over the process and reconciles the two belief systems with the imagery of the tāruke (crayfish trap) in which both the old and the new could co-exist (Te Runanganui o Ngāti Porou, 2019). Of the haka, Wiremu Kaa explained: 'Mohi [Turei] had come to the realisation that his taha Ngāti Porou [Ngāti Porou side] cannot be abandoned or trashed because the wairua [spirit] from his mātua [elders] and his tīpuna [ancestors] are the material essence of his being' (cited in Mahuika, 2015, p. 54). Referring to the interconnectedness of Ngāti Porou whakapapa and whakapono, Wiremu Kaa continues: 'Our individual tāruke [a container for catching fish] will always contain the wairua that is Ngāti Porou tūturu [authentically Ngāti Porou]. Whatever else we place in that tāruke is up to every Ngāti Porou individual' (cited in Mahuika, 2015, p. 54).

The significance of Taumata-ā-Kura is also recognised in the Church of St Mary's in Tikitiki (Te Runanganui o Ngāti Porou, 2019). This church was designed by master carver Hone Ngatoto and Sir Apirana Ngata as a purposeful statement about our identity as Ngāti Porou (Te Runanganui o Ngāti Porou, 2019). The church's Taumataa-Kura baptismal font (see Figure 13), signifies that when Ngāti Porou are baptised, they are not only being baptised as Christians, but also into the unique whakapapa and whakapono of Ngāti Porou (Te Runanganui o Ngāti Porou, 2019). 


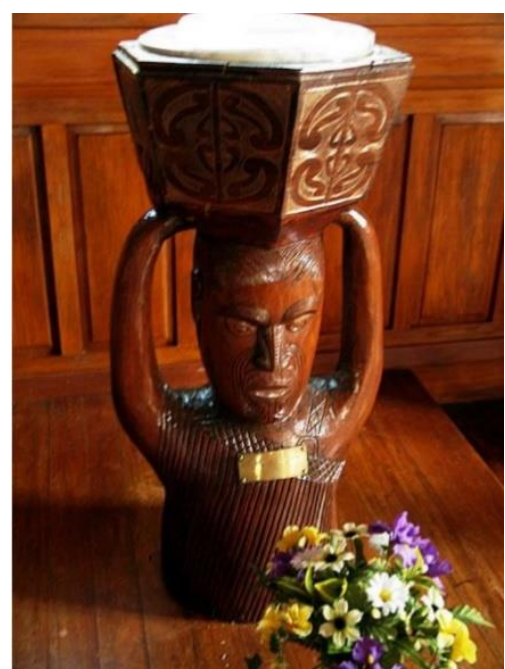

Figure 10. Taumata-ā-Kura baptismal font(Te Runanganui o Ngāti Porou, 2019).

I remain a practising Anglican. However, as a selfprofessed syncretist, I incorporate into my faith-as Harrison (2014) advised-other wisdoms and traditions that are beneficial to me as I question life's purpose and search for answers for life's questions. I am constantly engaged in researching religion, to understand myself and the world around me more deeply. Taoism and Hinduism have been two notable influences on my theology, but there are many others.

\section{Syncretistic 'Odds and Ends': Taoist and Hindu Influences}

In 2016, I received the Tao and the Three Treasures in a small temple in a Rotorua backyard from a Master who had travelled from Indonesia. I received the Tao with other members of my extended family from Waiohau, who are healers and rongoā (Māori medicine) practitioners. Tao is considered one of the most important concepts in the East (Sung Park, 2001). Tao means way, road or path, and 'metaphorically denotes a way of living and truth' (Sung Park, 2001, p. 389). According to Sung Park (2001), Tao refers to the 'eternal Tao', the 'Ultimate Way', the 'Endless 
Dynamic Principle of the universe' (p. 390) and 'the Cosmic Way, reflecting the unending rhythm of the universe' ( $\mathrm{p}$. 394). It may also be described as 'the force that transcends all forces ... the principle that governs all natural laws' and that which 'moves everything forward, including time, life, all the stars and planets' (True Tao, 2016, n.p.). While words are unable to fully express the Tao, it is 'the origin of everything that exists, or the creator of the universe. Many people call this creator God' (True Tao, 2016, n.p.).

In the ceremony, I received the Three Treasures: the Mystic Portal, the Mantra and the Covenant. The Mystic Portal is described as 'right door' or 'proper doorway' and is pointed between the eyes and opened by a Master. It is understood as the door to the soul, a portal for connecting with others, keeping thoughts tranquil and clear, and even perceiving danger (True Tao, 2016, n.p.). The Mantra is a sacred and unwritten phrase that, when uttered in the mind in times of distress, provides a wellspring of strength $\ldots$ as if the Buddhas have come to your aid' (True Tao, 2016, n.p.). The Covenant is a 'gesture where the left hand holds the right in a symbolic representation of the tender loving care that you feel when you hold an infant in your arms' and is 'a reminder of the child within us, our original nature beyond good and bad, right and wrong, judgement and criticism' (True Tao, 2016, n.p.). The Three Treasures are described as powerful ways that one can ensure safety, regain calmness and deepen meditation (True Tao, 2016, n.p.).

Through receiving the Tao, I reflected on my Christian faith. 'As Jews and Christians serve the unutterable YHWH, Asians have revered the nameless Tao' (Sung Park, 2001, p. 389). Sung Park (2001) related the 'nameless Tao' to YHWH and argued that, concerning the 'Yahwist tradition, God's identity is mysterious' (p. 391). According to Ellison (1982), many scholars have argued that YHWH should be understood, grammatically, in a future form, as 'I will be that I will be' rather than 'I am that I am' (Exodus 3:14 KJV). Understanding YHWH in this way, Sung Park (2001) argued, indicates that God is indecipherable, inscrutable, and unfathomable' (p. 391). As a Christian who was initiated into the Tao, I can accept the belief that 'the eternal Tao became flesh in Jesus Christ, the visible Tao' (Sung Park, 2001, p. 398). From a Sino-Christological perspective, Wan (2003) described Jesus Christ as 'tien- 
ren-he-yi-di-tao' or 'heaven-man-unite-one-tao' (p. 5). Of Jesus, Sung Park (2001) wrote: 'He came to show the way of living according to God's purpose in creation. Jesus Christ did not seek to establish institutional religion, but to spread the word of God. He is the visible Tao or the mandate of heaven' (p. 398).

I visited a Hindu temple for the first time early in 2019; however, many years earlier, I had been captivated by the images and stories of Hindu deities. Hinduism is both a religion and dharma, or right way of living (Rosen, 2006; Sharma, 2003). Hinduism is recognised as one of the oldest religions in the world (Bakker, 1997; Fowler, 1997; Klostermaier, 2014; Kurien, 2006; Noble, 1998; Swami Bhaskarananda, 2005). The concept of God in Hinduism, although virtually impossible for me to comprehend intellectually, is deeply mystifying and highly attractive to me.

In the eucharistic theology of Orthodox Christianity, the bread and wine become the body and blood of Jesus, but the process by which this takes place is a mystery (Ware, 1993). For me, God is the ultimate mystery. God, as Sung Park (2001) noted, cannot be comprehensively understood. Thus, I accept that cultures and peoples imagine, construct and perceive God in ways that I can only attempt to approach as a means of enriching my emerging and evolving sense of God. Sheth (2002) argued: "The similarities with other traditions help us to appreciate the larger significance of our beliefs and practices, and the difference give us insights into the unique features of our own tradition' (p. 98).

Lord Ganesha, the elephant-headed God, is the bestrecognised and most worshipped deity in Hinduism and is considered the Lord of Intelligence and Wisdom (Dutta, 2016; Dwyer, 2015; Kumar, Kalra \& Mahapatra, 2008). He is 'invoked before all Hindu ceremonies as the Lord of Beginnings and Remover of Obstacles' (Dwyer, 2015, p. 263). In addition to his wisdom and intelligence, he is also revered as the God of wealth, health, celibacy, fertility and happiness (Dutta, 2016). Shiva beheaded Ganesha when Ganesha came between Shiva and Parvati, and Shiva replaced his son's head with that of an elephant (Kumar et al., 2008). Kumar et al.'s (2008) article, Lord Ganesha: The idol neurosurgeon, related that the replacing of Ganesha's 
human head with an elephant's head is, in essence, a divine neurosurgical event.

I have owned and displayed various forms of Ganesha-whom I remain very fond of-in my home and office for more than a decade. The symbolism behind his physical attributes-which I apply to my life-is described as follows: wide ears to listen more; small mouth to speak less; large head and large brain to think and remember; small eyes to focus; two to 16 arms to accomplish great tasks, although Ganesha is usually shown with four arms (Dutta, 2016); one remaining, unbroken tusk to keep the good and discard the bad; a long trunk to be efficient and adaptable; and a large belly to digest the positives and negatives of life (Kumar et al., 2008).

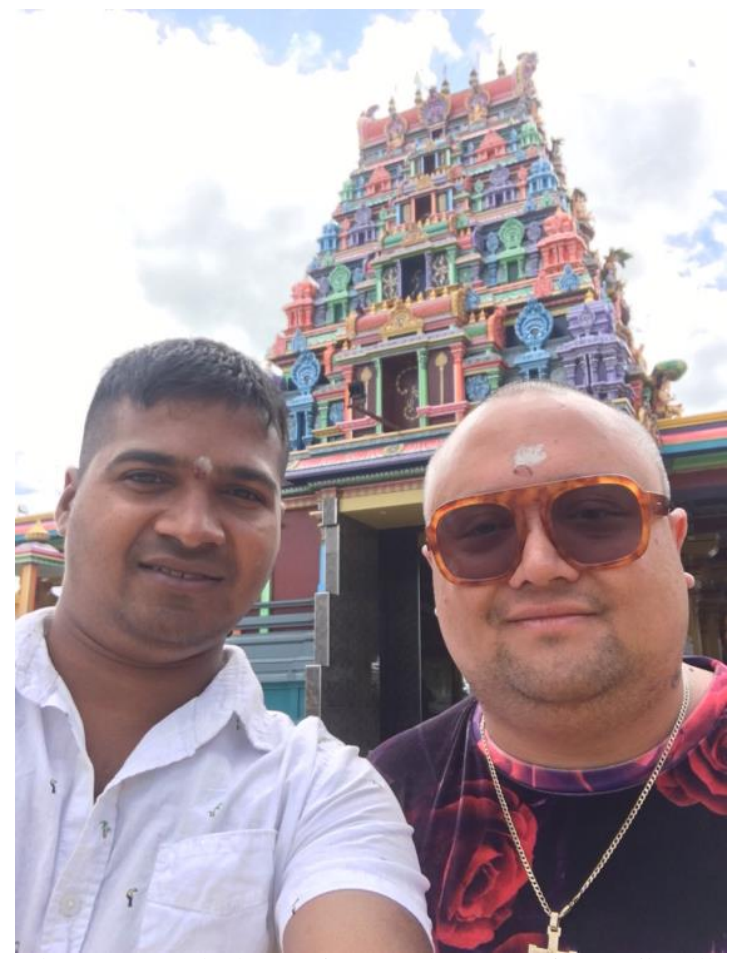

Figure 11. Sri Siva Subramaniya Temple, Nadi, Fiji, September 2019 


\section{Conclusion}

In this article, I have discussed and set the parameters of my faith-world based on whakapapa and whakapono. I have outlined the whakapapa links to whakapono-Patuheuheu and Ngāti Whare to Ringatū; Ngāti Manawa to Catholicism; and Ngāti Porou to Te Hāhi Mihinare. I have also described some of my experiences pertaining to Pentecostalism and Mormonism, and my lingering encounters with Taoism and Hinduism. This article expressed and discussed my encounters with religion and set the context for my unique and syncretistic theological position. 


\section{Bibliography}

Adas, M. (1979). Prophets of rebellion: Millenarian protest movements against the European colonial order. Chapel Hill, NC: University of North Carolina Press.

Adams, P. (2013). Fatal necessity: British intervention in New Zealand, 1830-1847. Wellington, New Zealand: Bridget Williams Books.

Akenson, D. (2005). An Irish history of civilisation (vol. 2). Montreal, Canada: McGill-Queen's University Press.

Aldhouse-Green, M. (2004). An archaeology of images: Iconology and cosmology in Iron Age and Roman Europe. London, England: Routledge.

Alves, D. (1999). The Maori and the Crown: An indigenous people's struggle for self-determination. Westport, CT and London, England: Greenwood Press.

Andersen, P. B. (2009). Revival, syncretism, and the anticolonial discourse of the Kherwar Movement, 1871-1910. In R. F. Young (Ed.), India and the Indianness of Christianity: Essays on understanding-historical, theological, and bibliographical-in honor of Robert Eric Frykenberg (pp. 127-143). Grand Rapids, MI: William B. Eerdmans.

Anderson, B. W. (1975). Understanding the Old Testament (3rd ed.). Englewood Cliffs, NJ: Prentice-Hall.

Anderson, H. (2016). Indigenous innovations on music and Christianity at Ratana Pa. In S. A. Reily \& J. M. Dueck (Eds.), The Oxford handbook of music and world Christianities (pp. 96-119). New York, NY: Oxford University Press.

Anderson, J. (2019). Redeeming the redeemer: Representations of an Indigenous Christ in James K. Baxter's 'The Maori Jesus', Patricia Grace's Potiki and Moetai Brotherson's Le Roi absent. Journal of New Zealand Literature, 36(2), 117130.

Anderson, A., Binney, J. \& Harris, A. (2015). Tangata whenua: A history. Wellington, New Zealand: Bridget Williams Books.

Anglican Church in Aoteaora, New Zealand and Polynesia (2005). A New Zealand prayer book/He karakia Mihinare o Aotearoa. Christchurch, New Zealand: Genesis.

Apter, A. (2004). Herskovits's heritage: Rethinking syncretism in the African diaspora. In A. M. Leopold \& J. S. Jensen 
(Eds.), Syncretism in religion: A reader (pp. 160-184). New York, NY: Routledge.

Arapere, B. (2002). A history of the Waiohau blocks: A report commissioned by the Waitangi Tribunal (Wai 894 \#A26). Wellington, New Zealand: Waitangi Tribunal.

Auckland Star (1905, June 8). Report of the Auckland Supreme Court hearing of the title. Vol. 37, No. 136. Retrieved from: http: / / paperspast.natlib.govt.nz/cgi-

bin/paperspast?a=d\&d=AS19050608.2.54\&e=-------10--1---0--

Auckland Star. (1914, March 14). Shipping. Vol. 45, No.61. Retrieved from: http://paperspast.natlib.govt.nz/cgibin $/$ paperspast?a $=\mathrm{d} \& \mathrm{~d}=\mathrm{AS} 19140312.2 .8$

Auckland Weekly News. (1906, 15 February). Native land dispute at Galatea [photograph]. Sir George Grey Special Collections. (7-A14283).

Badrinath, C. (2000). Finding Jesus in Dharma: Christianity in India. Delhi, India: Indian Society for Promoting Christian Knowledge.

Bahr, A. M. B. (2005). Indigenous religions. New York, NY: Chelsea House.

Baird, R. D. (2004). Syncretism and the history of religions. In A. M. Leopold \& J. S. Jensen (Eds.), Syncretism in religion: $A$ reader (pp. 48-58). New York, NY: Routledge.

Bakker, F. L. (1997). Balinese Hinduism and the Indonesian State: Recent developments. Journal of the Humanities and Social Sciences of Southeast Asia, 153(1), 15-41.

Ballantyne, T. (2002). Orientalism and race: Aryanism in the British Empire. New York, NY: Palgrave.

Ballantyne, T. (2012). Webs of empire: Locating New Zealand's colonial past. Wellington, New Zealand: Bridget Williams Books.

Ballantyne, T. (2015). Entaglements of empire: Missionaries, Māori, and the question of the body. Auckland, New Zealand: Auckland University Press.

Ballara, A. (1986). Proud to be white: A survey of Pakeha prejudice in New Zealand. Auckland, New Zealand: Heinemann.

Ballard, R. (2009). Granpa's call: Conscience, ethics, and aporias. Qualitative Inquiry, 15, 467-482.

Banner, S. (2007). Possessing the Pacific. London, England: Harvard University Press. 
Barber, I. (1995). Between biculturalism and assimilation: The changing place of Maori culture in the twentieth-century New Zealand Mormon Church. New Zealand Journal of History, 29(2), 142-169.

Barker, D. (1970). Maori sectarianism: Ringatu and Ratana: Towards a theology of culture. Auckland, New Zealand: The Presbytery of South Auckland.

Bastide, R. (1978). The African religions of Brazil: Toward a sociology of the interpenetration of civilizations $(\mathrm{H}$. Sebba, Trans.). Baltimore, MD: Johns Hopkins University Press.

Battiste, M. (2000). Reclaiming indigenous voice and vision. Seattle, WA: University of Washington Press.

Bawden, P. (1987). The years before Waitangi: A story of early Maori/European contact in New Zealand. Auckland, New Zealand: Benton Ross.

Baxter, J. K. (1988). Collected poems James K Baxter. Oxford, United Kingdom: Oxford University Press.

Beatson, E. J. (2002). Becoming a three tikanga church: The bicultural commission on the revision of the constitution 19861992 (Unpublished master's thesis). Massey University, Palmerston North, New Zealand.

Belgrave, M. (2018). He mōrearea, he kariritanga, he whakatikatanga: Crisis and conflict, resistance and readjustment, 1863-1881. In M. Reilly, S. Duncan, G. Leoni, L. Paterson, L. Carter, M. Rātima \& P. Rewi (Eds.), Te Kōparapara: An introduction to the Māori world (pp. 209223). Auckland, New Zealand: Auckland University Press.

Belich, J. (1986). The New Zealand wars. Auckland, New Zealand: Penguin.

Belich, J. (1996). Making peoples: A history of the New Zealanders from Polynesian settlement to the end of the nineteenth century. Auckland, New Zealand: Penguin.

Belich, J. (2001). Paradise forged: A history of the New Zealanders from the 1880s to the year 2000. Auckland, New Zealand: Penguin.

Bennett, M. \& MacKenzie, K. (Directors). (2011). Whare Māori [Motion picture]. Auckland, New Zealand: Scottie Productions.

Berling, J. A. (1980). The syncretic religion of Lin Chao-en. New York, NY: Columbia University Press.

Berner, U. (2004). The concept of 'syncretism': An instrument of historical insight/discovery? In A. M. Leopold \& J. S. 
Jensen (Eds.), Syncretism in religion: A reader (pp. 295315). New York, NY: Routledge.

Best, E. (1978). Some aspects of Maori myth and religion. Wellington, New Zealand: Dominion Museum \& Government Printer.

Binney, J. (1983). Maungapohatu revisited: Or, how the government underdeveloped a Maori community. Journal of the Polynesian Society, 92(3), 353-392.

Binney, J. (1984). Myth and explanation in the Ringatu tradition: Some aspects of the leadership of Te Kooti Arikirangi Te Turuki and Rua Kēnana Hepetipa. Journal of the Polynesian Society, 93(4), 345-398.

Binney, J. (1988). The Ringatu traditions of predictive history. The Journal of Pacific History, 23(2), 167-174.

Binney, J. (1996). Māori prophet leaders. In K. Sinclair (Ed.), The Oxford illustrated history of New Zealand (pp. 153-184). Melbourne, Australia: Oxford University Press.

Binney, J. (1997). Redemption songs: A life of Te Kooti Arikirangi Te Turuki. Auckland, New Zealand: University Press and Bridget Williams.

Binney, J. (2001a). Maori oral narratives: Pakeha written texts. In J. Binney (Ed.), The shaping of history-essays from the New Zealand Journal of History (pp. 2-14). Wellington, New Zealand: Bridget Williams.

Binney, J. (2001b). Te Umutaoroa: The earth oven of long cooking. In A. Sharp \& P. McHugh (Eds.), Histories, power and loss: Uses of the past-a New Zealand commentary (pp. 146-64). Wellington, New Zealand: Bridget Williams.

Binney, J. (2005). The legacy of guilt: A life of Thomas Kendall. Wellington, New Zealand: Bridget Williams.

Binney, J. (2007a). Papahurihia, Pukerenga, Te Atua Wera and Te Nākahi: How many prophets? The Journal of the Polynesian Society, 116(3), 309-320.

Binney, J. (2007b). Te Kooti Arikirangi Te Turuki ?-1893. In, Dictionary of New Zealand Biography. Retrieved from http://www.dnzb.govt.nz/DNZB/alt_essayBody.asp?essayI $\mathrm{D}=1 \mathrm{~T} 45$

Binney, J. (2007c). When the white kawau flies. In J. Lutz (Ed.), Myth and memory: Stories of Indigenous-European contact (pp. 140-159). Vancouver, Canada: UBC Press.

Binney, J. (2009a). Encircled lands: Te Urewera, 1820-1921. Wellington, New Zealand: Bridget Williams. 
Binney, J. (2009b). Te upokokohua: The curse of confiscation on Te Urewera. In R. Boast \& R. S. Hill (Eds.), Raupatu: The confiscation of Maori land (pp. 222-232). Wellington, New Zealand: Victoria University Press.

Binney, J. (2010). Stories without end: Essays 1975-2010. Wellington, New Zealand: Bridget Williams.

Binney, J. (2011). Māori prophetic movements-Ngā poropiti. Retrieved from https://teara.govt.nz/en/maori-propheticmovements-nga-poropiti

Binney, J. (2012). Mãori prophetic movements-Ngā poropiti. Retrieved from http://www.TeAra.govt.nz/en/nga-poropitimaori-prophetic-movements / page-1

Binney, J. (2014). The coming of the Pākehā 1820-1840. In A. Anderson, J. Binney \& A. Harris (Eds.), Tangata whenua: An illustrated history (pp. 190-217). Wellington, New Zealand: Bridget Williams Books.

Binney, J. \& Chaplin, G. (1996). Ngā mōrehu—the survivors: The life histories of eight Maori women. Auckland, New Zealand: Oxford University Press \& Bridget Williams.

Binney, J., Chaplin, G., \& Wallace, C. (1979). Mihaia: The prophet Rua Kenana and his community at Maungapohatu. Auckland, New Zealand: Auckland University Press.

Boast, R. P. (2002). The Crown and Te Urewera in the 20th century-a study of government policy. Wellington, New Zealand: Waitangi Tribunal

Boast, R. (2008). Buying the land, selling the land. Wellington, New Zealand: Victoria University Press.

Boast, R. (2013). Vanished theocracies: Christianity, war and politics in colonial New Zealand 1830-80. In L. Ford \& T. Rowse (Eds.), Between indigenous and settler governance (pp. 70-82). New York, NY: Routledge.

Boff, L. (1985). Church: Charism and power: Liberation theology and the institutional church. London, England: SCM Press.

Bouma, G. D., Ling, R. \& Pratt, D. (2010). Religious diversity in Southeast Asian and the Pacific: National case studies. New York, NY: Springer.

Bouzereau, L. (Director/Producer). (2010). Raising Hell: Filming The Exorcist [Motion Picture]. Los Angeles, CA: Warner Bros.

Bowie, F. (2006). The anthropology of religion: An introduction (2nd ed.). Malden, MA: Blackwell.

Boyer, P. (2001). Religion explained: The evolutionary origins of religious thought. New York, NY: Basic Books. 
Braun, V., Clarke, V., Hayfield, N. \& Terry, G. (2019). Thematic analysis. In P. Liamputtong (Ed.), Handbook of research methods in health social sciences (pp. 843-860). Singapore: Springer Nature.

Brett, M. G. (2019). Exodus politics and colonial contestation. Journal of New Zealand Literature, 36(2), 131-146.

Brinkman, M. E. (2009). The non-Western Jesus: Jesus as bodhisattva, avatara, guru, prophet, ancestor or healer? $(\mathrm{H}$. $\&$ L. Jansen, Trans.). London, England: Equinox.

Brockman, D. R. (2011). No longer the same: Religious others and the liberation of Christian theology. New York, NY: Palgrave MacMillan.

Bromiley, G. W. (1995). The international standard Bible encyclopedia: $Q-Z$. Grand Rapids, MI: William B. Eerdsmans.

Brooking, T. (2004). The history of New Zealand. Westport, CT: Greenwood.

Brown, D. (2009). Māori architecture: From fale to wharenui and beyond. Auckland, New Zealand: Penguin.

Buck, P. (1950). The coming of the Maori. Wellington, New Zealand: Whitcombe \& Tombs.

Budd, G. (1939). The story of Maori missions: Being five studies. Auckland, New Zealand: Presbyterian Women's Missionary Union.

Buddle, T. (1861, 28 June). Thomas Buddle to Col. Thomas Gore Browne. (Appendices to the Journals of the House of Representatives, 1861, E-IH)

Buerger, D. J. (1987). The development of the Mormon temple endowment ceremony. Dialogue: A Journal of Mormon Thought, 20(4), 33-76.

Buerger, D. J. (1994). The mysteries of godliness: A history of Mormon temple worship. San Francisco, CA: Smith Research Associates.

Cal, A. P. (1997). The old face of the new evangelization. In G. Cook (Ed.), Crosscurrents in indigenous spirituality: Interface of Maya, Catholic and Protestant worldviews (pp. 217-223). Leiden, Netherlands: E. J. Brill.

Callaghan, M. (2014). Nineteenth-century Wairoa District Mission: Missionary/Māori 'entanglement'. In A. Davidson, S. Lange, P. Lineham \& A. Puckey (Eds.), Te Rongopai 1814 'Takoto te pail': Bicentenary reflections on Christian beginnings and developments in Aotearoa New Zealand (pp. 175-190). Auckland, New Zealand: The General Synod 
Office of the Anglican Church in Aotearoa New Zealand and Polynesia.

Calman, R. (2012). Mãori education-Mātauranga. Retrieved from https://teara.govt.nz/en/maori-educationmatauranga/print

Cameron, G. (2015). "That you might stand here on the roof of the clouds." The development of Pirirākau theology from encounter to the end of conflict, 1839-1881. Unpublished master's thesis, University of Otago, Dunedin, New Zealand.

Cameron, A. \& Forbes, A. (n.d.). About us. Pastoral area of Saint Mary of the Cross, Rotorua. Retrieved from http://www.catholicrotorua.org.nz/index.php/aboutus/history

Canty, A. (2011). Light and glory: The transfiguration of Christ in early Franciscan and Dominican theology. Washington, D.C.: Catholic University of American Press.

Carew, P. \& Troughton, G. (2012). Māori participation in the Assemblies of God. In H. Morrison, L. Paterson, B. Knowles $\&$ M. Rae (Eds.), Mana Māori and Christianity (pp. 91-110). Wellington, New Zealand: Huia.

Cheater, A. \& Hopa, N. (1997). Representing identity. In A. James, J. Hockey \& A. Dawson (Eds.), After writing culture: Epistemology and praxis in contemporary anthropology (pp. 208-23). Oxon, England: Routledge.

Chouiter, L. \& Annoni, J. (2018). Glossolalia and aphasia: Related but different worlds. In J. Bogousslavsky (Ed.), Neurologic-psychiatric syndromes in focus. Part II-From psychiatry to neurology (pp. 96-105). Basel, Switzerland: Karger.

Chung, D. (2001). Syncretism: The religious context of Christian beginnings in Korea. Albany, NY: State University of New York Press.

Church, I. (1990). Poutama, Te Manihera. Te Ara-Encyclopedia of New Zealand. Retrieved from https://teara.govt.nz/en/biographies/1p27/poutama-temanihera

Church Missionary Society. (1816). Missionary register. London, United Kingdom: L. B. Seeley \& Sons.

Church Missionary Society. (1829). Missionary register. London, United Kingdom: L. B. Seeley \& Sons. 
Church Missionary Society. (1838-1839). Proceedings of the Church Missionary Society for Africa and the East. London, UK: Author.

Church of England in New Zealand. (1880). Church gazette for the Diocese of Auckland. Auckland, New Zealand: Author.

Clack, T. (2011). Syncretism and religious fusion. In T. Insoll (Ed.), The Oxford handbook of the archaeology of ritual and religion (pp. 226-242). Oxford, England: Oxford University Press.

Clandinin, D. J. \& Connelly, F. M. (2000). Narrative inquiry: Experience and story in qualitative research. San Francisco, CA: Jossey-Bass.

Coleman, J. N. (1865). A memoir of the Rev. Richard Davis, for thirty-nine years a missionary in New Zealand. London, UK: John Nisbet.

Colenso, W. (1868). On the Maori races of New Zealand. Transactions and Proceedings of the New Zealand Institute, $1,385$.

Colenso, W. (1890). The authentic and genuine history of the signing of the Treaty of Waitangi, New Zealand, February 5 and 6, 1840: Being a faithful and circumstantial, though brief, narration of events which happened on that memorable occasion; with copies of the Treaty in English and Maori, and of the three early proclamations respecting the founding of the colony. Wellington, New Zealand: Government Printer.

Comay, J. (2002). Who's who in the Old Testament. London, England: Routledge.

Coogan, M. D., Brettler, M. Z., Newsom, C. A. \& Perkins, P. (Eds.). (2010). The new Oxford annotated Bible. New York, NY: Oxford University Press.

Cook, G. \& Nayap-Pot, D. (1997). Conclusion. In G. Cook (Ed.), Crosscurrents in indigenous spirituality: Interface of Maya, Catholic and Protestant worldviews (pp. 293-321). Leiden, Netherlands: E. J. Brill.

Cooper, G. (2017). Gods and Kaupapa Māori research. In T. Hoskins \& A. Jones (Eds.), Critical conversations in Kaupapa Mãori (pp. 147-159). Wellington, New Zealand: Huia.

Cooper, I. S. (2010). Ceremonies of the Liberal Catholic Rite (6th ed.). San Diego, CA: St. Alban Press.

Copeland, K. (2010). The laws of prosperity. Bath, England: Kennth Copeland Ministries. 
Cowan, J. (1922). The New Zealand wars: A history of the Maori campaigns and the pioneering period, 1864-72. Wellington, New Zealand: Government Printer.

Cowan, J. (1930). The Maori yesterday and to-day. Christchurch, New Zealand: Whitcombe \& Tombs.

Cowan, J. (1938). The facts about Te Kooti: How injustice made a rebel: The true story of his transportation. The New Zealand Railways Magazine, 13(9), 17-21.

Cox, L. (1993). Kotahitanga: The Maori search for political unity. Auckland, New Zealand: Oxford University Press.

Cox, N. (2008). The Anglican Church and its decision-making structures. SSRN. Retrieved from https://papers.ssrn.com/sol3/papers.cfm?abstract_id=114 $\underline{0465}$

Creegan, N. H. (2005). Jesus in the land of spirits and utu. Pacifica: Australasian Theological Studies, 18(2), 141-153.

Crosby, R. D. (2001). The Musket Wars: A history of inter-iwi conflict, 1806-45. Auckland, New Zealand: Reed.

Crosby, R. (2004). Gilbert Mair: Te Kooti's nemesis. Auckland, New Zealand: Reed.

Cutimanco, G. (1997). Christianity and aboriginal religions in Abia Yala. In G. Cook (Ed.), Crosscurrents in indigenous spirituality: Interface of Maya, Catholic and Protestant worldviews (pp. 49-59). Leiden, Netherlands: E. J. Brill.

Darragh, N. (2003). Contextual method in theology: Learnings from the case of Aotearoa New Zealand. Pacifica: Australasian Theology Studies, 16(1), pp. 45-66.

Davidson, A. K. (2004). Christianity in Aotearoa: A history of church and society in New Zealand. Wellington, New Zealand: The New Zealand Education for Ministry Board.

Davidson, A. (2018). Anglican Church-Anglicans in the 20th and 21st centuries. Retrieved from https://teara.govt.nz/en/anglican-church/page-3

Davidson, A. K. \& Lineham, P. J. (1995). Transplanted Christianity: Documents illustrating aspects of New Zealand church history. Palmerston North, New Zealand: Department of History, Massey University.

Davidson, A. K., Lange, S., Lineham, P. J. \& Millar, A. (2014). Te Rongopai 1814 'Takoto te pai': Bicentenary reflections on Christian beginnings and developments in Aotearoa New Zealand and Polynesia. Auckland, New Zealand: General Synod Office. 
de Bres, P. H. (1980). The Maori contribution. In B. Colless \& P. Donovan (Eds.), Religion in New Zealand society (pp. 3155). Palmerston North, New Zealand: Dunmore Press.

Delio, I. (1992). 'The canticle of brother Sun': A song of Christ mysticism. Franciscan Studies, 52, 1-22.

Dempsey, G. J. (1990). Waitoa, Rota. Te Ara-Encyclopedia of New Zealand. Retrieved from https://teara.govt.nz/en/biographies/1w2/waitoa-rota

Dennison, J. (2005). Ko te Pakeha te teina: Baxter's crosscultural poetry. Journal of New Zealand Literature, 23(2), $36-46$.

Derry, K. (2011). Indigenous traditions. In W. G. Oxtoby \& A. Hussain (Eds.), World religions: Western traditions (pp. 322385). Ontario, Canada: Oxford University Press.

Doniger, W. (Ed.). (1999). Merriam-Webster's encyclopedia of world religions. Springfield, MA: Merriam-Webster Incorporated.

Douglas, E. T. \& Boxill, I. (2012). The lantern and the light: Rastafari in Aotearoa (New Zealand). In M. Barnett (Ed.), Rastafari in the new millennium: A Rastafari reader (pp. 3565). Syracuse, NY: Syracuse University Press.

Douglas, M. (Producer), Hakaraia, L. \& Stephens, T. (Directors). (2013). The prophets [Motion Picture]. Auckland, New Zealand: Scottie Productions.

Doyle, E. (1974). Ecology and the Canticle of Brother Sun. New Blackfriars, 55(652), 392-402.

Droogers, A. (1989). Syncretism: The problem of definition, the definition of the problem. In J. Gort, H. Vroom, R. Fernhout \& A. Wessels (Eds.), Dialogue and syncretism: An interdisciplinary approach (pp. 7-25). Grand Rapids, MI: William B. Eerdsman.

Duncan, S. \& Rewi, P. (2018). Tikanga: How not to get told off! In M. Reilly, S. Duncan, G. Leoni, L. Paterson, L. Carter, M. Rātima \& P. Rewi (Eds.), Te kōparapara: An introduction to the Māori world (pp. 30-47). Auckland, New Zealand: Auckland University Press.

Dutta, S. (2016). A monograph on the elephant-headed God Ganesha: The mythological concept and distinct iconography. In Asian Elephants in Culture and Nature (pp. 70-76). Centre for Asian Studies, University of Kelaniya, Sri Lanka.

Dwyer, R. (2015). Vighnaharta Shree Siddhivinayak: Ganesh, remover of obstacles, Lord of beginnings in Mumbai. 
Comparative Studies of South Asia, Africa and the Middle East, 35(2), 263-276.

Edwards, P. N. (2001). The 1917 or Pio-Benedictine code of canon law: In English translation with extensive scholarly apparatus. San Francisco, CA: Ignatius Press.

Elder, J. R. (1932). The letters and journals of Samuel Marsden, 1765-1838 senior chaplain in the colony of New South Wales and Superintendent of the Mission of the Church Missionary Society in New Zealand. Dunedin, New Zealand: Coulls, Somerville, Wilkie \& A. H. Reed for the Otago University Council.

Elder, J. R. (1934). Marsden's lieutenants. Dunedin, New Zealand: Coulls, Somerville \& Wilkie.

Eller, J. D. (2007). Introducing anthropology of religion. New York, NY: Routledge.

Ellis, C. \& Bochner, A. (2006). Analyzing analytic autoethnography: An autopsy. Journal of Contemporary Ethnography, 35, 429-449.

Ellison, H. L. (1982). Exodus. Philadelphia, PA: Westminster.

Elsmore, B. (1998). Te Kohititanga Marama: New moon, new world: The religion of Matenga Tamati. Auckland, New Zealand: Reed.

Elsmore, B. (1999). Mana from heaven: A century of Maori prophets in New Zealand. Auckland, New Zealand: Reed.

Elsmore, B. (2008). Like them that dream: The Maori and the Old Testament. Auckland, New Zealand: Reed.

Emerald, E. \& Carpenter, L. (2017). Autoethnography: Is my own story narrative research? In R. Dwyer, I. Davis \& E. Emerald (Eds.), Narrative research in practice: Stories from the field (pp. 27-46). Singapore, Malaysia: Springer.

Engelhardt, H. (2014). The constitution of the Anglican Church in Aotearoa, New Zealand and Polynesia: A model for Europe? Ecclesiastical Law Journal, 16(3), 340-350.

Esler, P. F. (1994). The first Christians in their social worlds: Social scientific approaches to New Testament interpretation. London, England: Routledge.

Feltmate, D. (2013). It's funny because it's true? The Simpsons, satire, and the significance of religious humour in popular culture. Journal of the American Academy of Religion, 81(1), 222-248.

Fillingham, D. (2016). When Jesus was a girl: Polymythic female Christ figures in Whale Rider and Steel Magnolias. Journal of Religion and Film, 14(1), 1-24. 
Forster, M. (2019). Restoring the feminine of indigenous environmental thought. Genealogy, 3(1), 1-13.

Fowler, J. D. (1997). Hinduism: Beliefs and practices. Sussex, England: Sussex Academic Press.

Friedkin, W. (Director). (1973). The exorcist [Motion picture]. Los Angeles, CA: Warner Bros.

Fuchs, S. (1965). Rebellious prophets: A study of messianic movements in Indian religions. London, England: Asia Publishing House.

Garrett, J. (1992). Footsteps in the sea: Christianity in Oceania to World War II. Geneva, Switzerland \& Suva, Fiji: World Council of Churches \& Suva, Fiji: Institute of Pacific Studies, University of South Pacific.

Gibson, D. B. (2012). From Chiefdom to State in early Ireland. Cambridge, England: Cambridge University Press.

Gibson, W. W. (1975). The Rev. James Duncan: First Presbyterian missionary to the Maori. Dunedin, New Zealand: Presbyterian Historical Society of New Zealand.

Girdwood-Morgan, K. (1985). J. B. F. Pompallier's instructions for mission work 1841 (Unpublished dissertation of social sciences). Massey University, Palmerston North, New Zealand.

Goosen, G. (2000). Syncretism and the development of doctrine. Colloquium, 32(2), 137-150.

Gordon, T. \& Hancock, M. (2005). 'The crusade is the vision': Branding charisma in a global pentecostal ministry. Material Religion: The Journal of Objects, Art and Belief, 1(3), 386-404.

Grace, T. S. (1865, 5 March). Journal of Rev. T. S. Grace. (Appendices to the Journals of the House of Representatives, A-5).

Grace, T. S. (1871, 28 January). T. S. Grace to CMS [Letter]. Wellington, New Zealand: Alexander Turnbull Library (micro. coll. 4. reel 51. Church Missionary Society Archives, C. N. /045).

Grau, M. (2011). Rethinking mission in the postcolony: Salvation, society and subversion. New York, NY: T \& T Clark International.

Greenwood, W. (1942). The upraised hand: The spiritual significance of the rise of the Ringatu faith. Wellington, New Zealand: The Polynesian Society.

Gualtieri, A. R. (1984). Christianity and native traditions: Indigenization and syncretism among the Inuit and Dene of 
the Western Artic. Notre Dame, IN: Cross Roads Publications.

Gundry, R. H. (1969). In my father's house are many monai. In M. Konradt (Ed.), Zeitschrift für die neutestamentliche Wissenschaft und die Kunde der alteren Kirche (pp. 68-72). Berlin, Germany: J. Ricker'sche (Alfred Töpelmann).

Hakaraia, L. \& Stephens, T. (Directors). (2013). The prophets [Motion picture]. Auckland, New Zealand: Scottie Productions.

Hamilton, A. (n.d.). Whakapakoko Atua [photograph]. (B.001173). Museum of New Zealand Te Papa Tongarewa.

Harrison, W. H. (2014). In praise of mixed religion: The syncretism solution in a multifaith world. London, England: McGill-Queen's University Press.

Harvard-Williams, P. (1961). Marsden and the New Zealand mission. Dunedin, New Zealand: University of Otago Press.

Haviland, W. A., Prins, H.E.L., Walrath, D. \& McBride, B. (2005). Cultural anthropology: The human challenge. Belmont, CA: Thomson Wadsworth.

Head, L. (1984). Te Ua and the Hau faith in the light of the Ua Rongopai notebook (Unpublished master's thesis). University of Canterbury, Christchurch, New Zealand.

Head, L. F. (1992). The gospel of Te Ua Haumene. Journal of the Polynesian Society, 101(1), 7-44.

Hedges, P. (2010). Controversies in interreligious dialogue and the theology of religions. London, England: SCM Press.

Henare, A. (2005). Museums, anthropology and imperial exchange. New York, NY: Cambridge University Press.

Herrera, M. D. (2004). Sanctus bells: History and use in the Catholic Church. San Luis Obispo, CA: Tixlini Scriptorium. Retrieved from http://www.ewtn.com/library/liturgy/sanctusbells.pdf

Herrera, M. D. (2011). Holy smoke: The use of incense in the Catholic Church. San Luis Obispo, CA: Tixlini Scriptorium. Retrieved from https://www.scribd.com/doc/170397802/Holy-SmokeThe-Use-of-Incense-in-the-Catholic-Church

Higgins, R. (2012). New Zealand: The Māori people. In M. D. Palmer \& S. M. Burgess (Eds.), The Wiley-Blackwell companion to religion and social justice (pp. 412-424). Chichester, England: Blackwell. 
Hill, M. (1994). Religion. In P. Spoonley, D. Pearson \& I. Shirley (Eds.), New Zealand Society: A sociological introduction (pp. 292-307). Palmerston North, New Zealand: Dunmore Press.

Hill, H. (2012). Te Ope Whakaora, the army that brings life: The Salvation Army and Māori. In H. Morrison, L. Paterson, B. Knowles \& M. Rae (Eds.), Mana Māori and Christianity (pp. 23-42). Wellington, New Zealand: Huia.

Hill, R. (2004). State authority, indigenous autonomy: CrownMaori relations in New Zealand/Aotearoa, 1900-1950. Wellington, New Zealand: Victoria University Press.

Hocking, W. E. (1958). The coming world civilization. London, England: George Allen \& Unwin.

Hollis, J. T. (2013). Te Atuatanga: Holding Te Karaitianatanga and Te Māoritanga together going forward (Unpublished doctoral thesis). University of Canterbury, Christchurch, New Zealand.

Holman-Hunt, W. (1905). Pre-Raphaelitism and the preRaphaelite brotherhood. London, United Kingdom: Macmillan.

Hooper, T. (Director). (1982). Poltergeist [Motion picture]. Beverly Hills, CA: Metro-Goldwyn-Mayer Studios.

Hori, I. (1968). Folk religion in Japan: Continuity and change. Chicago, IL: University of Chicago Press.

Howe, K. R. (1990). Morgan, John. Te Ara-Encyclopedia of New Zealand.

Retrieved

from https://teara.govt.nz/en/biographies/1m55/morgan-john

Howe, K. R. (2005). Ideas of Mãori origins-1770s-1840s: Early ideas. Retrieved from https://teara.govt.nz/en/ideas-ofmaori-origins / page- 1

Hoxworth, K. (2017). Strains of the Enlightenment: Making belief in American secularism and African difference in The Book of Mormon. Modern Drama, 60(3), 364-386.

Hughes, D. A. (1988). Syncretism. In S. B. Ferguson \& D. F. Wright (Eds.), New dictionary of theology (p. 670). Downers Grove, IL: InterVarsity Press.

Humm, A. (2009). Psychology of prophecy in early Christianity: Prophetism and religious altered states of consciousness. Piscataway, NJ: Gorgias Press.

Imbach, S. R. (1984). Syncretism. In W. A. Elwell (Ed.), Evangelical dictionary of theology (1062-1063). Grand Rapids, MI: Baker.

Iq', W. (1997). Christian and Mayan spirituality: A dialogue. In G. Cook (Ed.), Crosscurrents in indigenous spirituality: 
Interface of Maya, Catholic and Protestant worldviews (pp. 241-260). Leiden, Netherlands: E. J. Brill.

Jackson, M. (2007). Globalisation and the colonising state of mind. In M. Bargh (Ed.), Resistance: An indigenous response to neoliberalism (pp. 167-182). Wellington, New Zealand: Huia.

Johns, S. M. (2013). Gender, nation and conquest in the high middle ages: Nest of Deheubarth. Manchester, England: Manchester University Press.

Jones, S. H. (2003). The way we were, are and might be: Torch singing as autoethnography. In Y. S. Lincoln \& N. K. Denzin (Eds.), Turning points in qualitative research: Tying the knots in a handkerchief (pp. 105-118). Walnut Creek, CA: AltaMira Press.

Jones, A. \& Jenkins, K. (2011). Words between us-he kōrero: First Māori-Pākehā conversations on paper. Wellington, New Zealand: Huia.

Jones, I. \& Webster, P. (2006). The theological problem of popular music for worship in contemporary Christianity. Crucible: The Journal of Christian Social Ethics, JulySeptember, 9-16.

Jørgensen, J. A. (2013). Indigenization, syncretism and the assumed boundedness of Christianity: A critique. In A. Adogame \& S. Shankar (Eds.), Religion on the move! New dynamics of religious expansion in a globalizing world (pp. 99-111). Leiden, Netherlands: Koninklijke Brill NV.

Joseph, R. (2012). Intercultural exchange, matakite Maori and the Mormon Church. In H. Morrison, L. Paterson, B. Knowles \& M. Rae (Eds.), Mana Māori and Christianity (pp. 43-72). Wellington, New Zealand: Huia.

Kaa, H. (2014). He ngākau hou: Te Hāhi Mihinare and the recognition of mätauranga, c.1800-1992 (Unpublished doctoral thesis). University of Auckland, Auckland, New Zealand.

Kaa, H. (2017). Ngā hāhi-Māori and Christian denominations. Retrieved from https://teara.govt.nz/en/nga-hahi-maoriand-christian-denominations

Kalechofsky, R. \& Kalechofsky, R. (1984). Jewish writing from down under: Australia and New Zealand. Marblehead, MA: Micah.

Kaplan, S. (1995). Introduction. In S. Kaplan (Ed.), Indigenous responses to Western Christianity (pp. 1-8). New York, NY: New York University Press. 
Kawharu, M. \& Newman, E. (2018). Whakapaparanga: Social structure, leadership and whāngai. In M. Reilly, S. Duncan, G. Leoni, L Paterson, L. Carter, M. Rātima \& P. Rewi (Eds.), Te kōparapara: An introduction to the Mãori world (pp. 4864). Auckland, New Zealand: Auckland University Press.

Keane, B. (2011). Traditional Māori religion-ngā karakia a te Māori. Te Ara-Encyclopedia of New Zealand. Retrieved from https://teara.govt.nz/en/traditional-maori-religionnga-karakia-a-te-maori

Keane, B. (2012a). The first kotahitanga movements, 18341840. Te Ara-Encyclopedia of New Zealand. Retrieved from https: / teara.govt.nz/en/kotahitanga-unitymovements/page-1

Keane, B. (2012b). Kotahitanga movements around the $1860 \mathrm{~s}$. Te Ara-Encyclopedia of New Zealand. Retrieved from https: / / teara.govt.nz/en/kotahitanga-unitymovements / page-2

Keane, B. (2012c). Kotahitanga-unity movementsParliamentary unity movements, 1870 to 1900. Te AraEncyclopedia of New Zealand. Retrieved from http://www.TeAra.govt.nz/en/document/33590/te-paki-omatariki

Keane, B. (2013). Māori feasts and ceremonial eating-Hākari. Te Ara-Encyclopedia of New Zealand. Retrieved from https://teara.govt.nz/en/maori-feasts-and-ceremonialeating-hakari

Kee, J. C. \& Carr-Chellman, D. J. (2019). Paulo Freire, critical literacy, and indigenous resistance. Educational Studies, 55(1), 89-103.

Kempthorne, A. (1868, July 12). Journal. Hawke's Bay Museum, Napier, New Zealand.

Kernis, J. (2011, 27 June). Richard Bushman: 'The Book of Mormon' is like looking into a fun-house mirror; the reflection is hilarious but not really you [Blog post]. Retrieved from https: / / web.archive.org/web/20111206132857/http:/ /int hearena.blogs.cnn.com/2011/06/27/richard-bushmanthe-book-of-mormon-is-like-looking-into-a-fun-housemirror-the-reflection-is-hilarious-but-not-really-you /

Kidwell, C. S., Noley, H. \& Tinker, G. E. (2003). A Native American theology. New York, NY: Orbis.

Kim, S. (1983). 'The "Son of Man"' as the Son of God. Tübingen, Germany: Mohr Siebeck. 
King, T. (2005). The truth about stories: A native narrative. Minneapolis, MN: University of Minnesota Press.

Kippenberg, H. G. (2004). In praise of syncretism: The beginnings of Christianity conceived in the light of a diagnosis of modern culture. In A. M. Leopold \& J. S. Jensen (Eds.), Syncretism in religion: A reader (pp. 29-38). New York, NY: Routledge.

Kirch, P. V. (2000). On the roads of the winds: An archaeological history of the Pacific Islands before European contact. Oakland, CA: University of California Press.

Kirk, R. W. (2012). Paradise past: The transformation of the South Pacific, 1520-1920. Jefferson, NC: McFarland.

Klein, U. (2000). Belief-views on nature-Western environmental ethics and Maori world views. New Zealand Journal of Environmental Law, 4, 81-119.

Kline, J. (2018). Fleeing from and fighting with The Exorcist. Jung Journal: Culture \& Psyche, 12(2), 10-25.

Klostermaier, K. K. (2014). A concise encyclopedia of Hinduism. London, England: Oneworld Publications.

Knitter, P. (1985). No other name? A critical survey of Christian attitudes toward the world religions. London, England: SCM Press.

Knox, J. R. (1980). Inaestimabile donum: Instruction concerning worship of the eucharistic mystery. Retrieved from https://www.ewtn.com/library/PAPALDOC/JP2INAES.HT $\underline{\mathrm{M}}$

Kotuku, P. (1921). Interview. MSS 39:41A, Alexander Turnbull Library, Wellington, New Zealand.

Kraemer, H. (1938). The Christian message in a non-Christian world. New York, NY: Harper and Brothers.

Kraemer, H. (1956). The Christian message in a non-Christian world (3rd ed.). London, England: James Clarke \& Company.

Kumar, R., Kalra, S. K. \& Mahapatra, A. K. (2008). Lord Ganesha: The ideo neurosurgeon. Child's Nervous System, 24(3), 287-288.

Kurien, P. (2006). Multiculturalism and American religion: The case of Hindu Indian Americans. Social Forces, 85(2), 723741.

Kwok, P. (2005). Postcolonial imagination and feminist theology. Louisville, KY: Westminster John Knox Press.

Kyung, C. H. (1993). Struggle to be the sun again: Introducing Asian women's theology. Maryknoll, NY: Orbis. 
Landcare Research. (2019). Ngā tipu whakaoranga-Māori plant use database. Retrieved from https://maoriplantuse.landcareresearch.co.nz/WebForms/ default.aspx

Landes, R. (2004). Millennialism. In J. R. Lewis, The Oxford handbook of new religious movements (pp. 333-358). Oxford, England: Oxford University Press.

Lang, J. D. (1873). New Zealand in 1839; or four letters to Right Hon. Earl Durham, Governor of the New Zealand Land Company, on the colonization of that island, and on the present condition and prospects of its native inhabitants. With a preface and appendix for 1873. London, UK: Smith, Elder \& Co.

Lange, R. (1999). May the people live: A history of Maori health development 1900-1920. Auckland, New Zealand: Auckland University Press.

Laughton, J. G. (1960). Ringatuism and the Ratana Church. Papers from the National Library of New Zealand, Wellington, New Zealand.

Leoni, G., Wharerau, M. \& White, T. (2018). He tātai tuakiri: The 'imagined' criteria of Māori identity. In M. Reilly, S. Duncan, G. Leoni, L Paterson, L. Carter, M. Rātima \& P. Rewi (Eds.), Te kōparapara: An introduction to the Māori world (pp. 372-394). Auckland, New Zealand: Auckland University Press.

Leopold, A. M. (2009). Syncretism. In P. B. Clarke \& P. Beyer (Eds.), The world's religions: Continuities and transformations (pp. 695-708). London, England: Routledge.

Leopold, A. M. \& Jensen, J. S. (2004a). General introduction. In A. M. Leopold \& J. S. Jensen (Eds.), Syncretism in religion: A reader (pp. 1-12). New York, NY: Routledge.f

Leopold, A. M. \& Jensen, J. S. (2004b). Introduction to part II. In A. M. Leopold \& J. S. Jensen (Eds.), Syncretism in religion: A reader (pp. 14-28). New York, NY: Routledge.

Leopold, A. M. \& Jensen, J. S. (2004c). Introduction to part III. In A. M. Leopold \& J. S. Jensen (Eds.), Syncretism in religion: A reader (pp. 88-97). New York, NY: Routledge.

Leopold, A. M. \& Jensen, J. S. (2004d). Introduction to part IV. In A. M. Leopold \& J. S. Jensen (Eds.), Syncretism in religion: A reader (pp. 142-159). New York, NY: Routledge.

Light, T. (2004). Orthosyncretism: An account of melding in religion. In A. M. Leopold \& J. S. Jensen (Eds.), Syncretism 
in religion: A reader (pp. 325-347). New York, NY: Routledge.

Lineham, P. (2013). Destiny: The life and times of a self-made apostle. Auckland, New Zealand: Penguin.

Lineham, P. (2017). Sunday best: How the church shaped New Zealand and New Zealand shaped the church. Auckland, New Zealand: Massey University Press.

Lineham, P. J. (2018). Missions and missionaries-Māori converts. Retrieved from https://teara.govt.nz/en/missions-and-missionaries/page$\underline{5}$

Livingstone, E. A. (2013). The concise Oxford dictionary of the Christian Church. Oxford, England: Oxford University Press.

Lubanska, M. (2015). Muslims and Christians in the Bulgarian Rhodopes: Studies on religious (anti)syncretism. Berlin, Germany: De Gruyter Open.

Luzbetak, L. J. (1988). The Church and cultures: New perspectives in missiological anthropology. Maryknoll, NY: Orbis Books.

Lynn, C. D. (2009). Glossolalia influences on stress response among Apostolic Pentecostals (Unpublished doctoral dissertation). State University of New York, New York, NY.

MacGaffey, W. (1994). Kimbanguism and the question of syncretism in Zaïre. In T. D. Blakey, W. E. A. van Beek \& D. L. Thomson (Eds.), Religion in Africa: Experience and expression (pp. 241-256). London, England: James Currey.

Mackay, J. A. (1949). Historic Poverty Bay and the East Coast. Gisborne, New Zealand: Author.

MacLysaght, E. (2006). More Irish families. County Kildare, Ireland: Irish Academic Press.

Mahuika, A. T. \& Oliver, S. (1990). Taumata-a-Kura, Piripi. Te Ara-Encyclopedia of New Zealand. Retrieved from https://teara.govt.nz/en/biographies/1t19/taumata-akura-piripi

Mahuika, N. (2015). Re-storying Māori legal histories: Indigenous articulations in nineteenth-century Aotearoa New Zealand. Native American and Indigenous Studies, 2(1), 40-66.

Mahuta, R. T. (1974). Whaikoorero: A study of formal Maori speech (Unpublished master's thesis). University of Auckland, Auckland, New Zealand. 
Mahuta, R. (1990). Taawhiao's dream 1990 McMillan Brown [Lecture]. Hamilton, New Zealand: University of Waikato, Centre for Maaori Studies and Research

Mahuta, N. (1995). Te Poukai o Waahi: An historical background to the Waahi Poukai (Unpublished master's research essay). University of Auckland, Auckland, New Zealand.

Mahuta, R. T. (2011). Tawhiao, Tukaroto Matutaera Potatau Te Wherowhero. Te Ara-Encyclopedia of New Zealand. Retrieved from https://teara.govt.nz/en/biographies/2t14/tawhiaotukaroto-matutaera-potatau-te-wherowhero

Mair, G. (1923). Reminiscences and Maori stories. Auckland, New Zealand: Brett Printing and Publishing Company.

Marsden, M. (2003). The woven universe: Selected writings of Rev. Mãori Marsden. Ōtaki, New Zealand: Estate of Rev. Māori Marsden.

Mataamua, R. \& Temara, P. T. (2010). Ka mate kāinga tahi, ka ora kāinga rua: Tūhoe and the environment-The impact of the Tūhoe diaspora on the Tūhoe environment. In R. Selby, P. Moore \& M. Mulholland (Eds.), Māori and the environment: Kaitiaki (pp.95-107). Wellington, New Zealand: Huia.

Matenga, H. (1877, 2 July). Hemi Matenga of Ngatitoa to the Editor of Waka Maori. In Te Waka Maori o Niu Tirani, 13(13), pp. 192-193.

Mathews, N. (2012). Kaikatikīhama: 'Our most precious resource'. In H. Morrison, L. Paterson, B. Knowles \& M. Rae (Eds.), Mana Māori and Christianity (pp. 141-158). Wellington, New Zealand: Huia.

McLean, M. \& Orbell, M. (2004). Traditional songs of the Maori (3rd ed.) Auckland, New Zealand: Auckland University Press .

McConkie, B. (1966). Mormon doctrine. Salt Lake City, UT: Deseret Book Company.

McFarlane, J. (1841, 26 April). J. McFarlane to Rev. Dr Walsh [Letter]. In Home and foreign missionary record. Location: Church of Scotland.

McGuckin, J. A. (1986). The transfiguration of Christ in scripture and tradition. New York, NY: Edwin Mellen Press.

Mcintosh, J. (2019). Polyontologism: When 'syncretism' does not suffice. Journal of African Religions, 7(1), 112-120.

McKeefry, P. (1938). Fishers of men. Wellington, New Zealand: Whitcombe \& Tombe. 
McNab, R. (1908). Historical records of New Zealand (Vol. 1). Wellington, New Zealand: Government Printer.

McRae, C. (Producer), \& Stephens, T. (Director). (1998). The New Zealand Wars [Motion picture]. Auckland, New Zealand: Landmark Productions.

Mead, H. (1970). Inverted pou mua of Eripitana wharenui [photograph]. (PID374126). University of Auckland.

Mead, H. (ca. 1970-1972). Tama-ki-Hikurangi wharenui [photograph]. (PID530310). University of Auckland.

Mead, H. M. (2003). Tikanga Mãori: Living by Mãori values. Wellington, New Zealand: Huia Publishers.

Mead, H. M. \& Phillis, O. E. (1982). The abundant earth - Te one matua: The centennial of Ruataupare at Kokohinau marae. Te Teko, New Zealand: Te Komiti Maori o Kokohinau.

Melbourne, T. (2011). Te wairua kōmingomingo o te Māori: The spiritual whirlwind of the Mãori (Unpublished doctoral thesis). Massey University, Palmerston North, New Zealand.

Metge, J. (1976). The Maoris of New Zealand: Rautahi. London, England: Routledge and Kegan Paul.

Meyer, B. (1994). Beyond syncretism: Translation and diabolization in the appropriation of Protestantism in Africa. In C. Stewart \& R. Shaw (Eds.), Syncretism/antisyncretism: The politics of religious synthesis (pp. 45-68). London, England: Routledge.

Middleton, A. (2008). Te Puna-A New Zealand mission station: Historical archaeology in New Zealand. New York, NY: Springer.

Mika, C. \& Tiakiwai, S. (2017). Tawhiao's unstated heteroglossia: Conversations with Bakhtin. Educational Philosophy and Theory, 49(9), 854-866.

Mikaere, A. (2005). Cultural invasion continued: The ongoing colonisation of tikanga Māori. Yearbook of New Zealand Jurisprudence, 8(2), 134-172.

Mikaere, A. (2011). Colonising myths-Mãori realities: He rukuruku whakaaro. Wellington, New Zealand: Huia.

Mikaere, A. (2016). Te harinui: Civilising Māori with school and church. In J. Hutchings \& J. Lee-Morgan (Eds.), Decolonisation in Aotearoa: Education, research and practice (pp. 48-57). Wellington, New Zealand: NZCER Press.

Miller, H. (1998). Maori and missionary: A sketch of the work of the Church Missionary Society's agents in New Zealand 1814-1864. Christchurch, New Zealand: Kiwi Publishers. 
Minutes of the Special Conference of Missionaries held at Auckland June 22. (1866). Remarks \&c of the Bishop of $N$. Zealand upon extracts of parent com'ees letter \& upon resolutions of conference. Wellington, New Zealand: Alexander Turnbull Library.

Misur, G. Z. (2003). From prophet cult to established church: The case of the Ringatu movement. In I. H. Kawharu (Ed.), Conflict and compromise: Essays on the Maori since colonisation (pp. 97-115). Auckland, New Zealand: Reed.

Moetara, S. (2012). Māori and Pentecostal Christianity in Aotearoa New Zealand. In H. Morrison, L. Paterson, B. Knowles \& M. Rae (Eds.), Mana Māori and Christianity (pp. 73-90). Wellington, New Zealand: Huia.

Moon, P. (1993). Maori social and economic history to the end of the nineteenth century. Auckland, New Zealand: Birdwood.

Moon, P. (2011). Nākahi: The Matarahurahu cult of the snake. Te Kaharoa: The e-Journal on Indigenous Pacific Issues, 4(1), 119-137.

Moorfield, J. C. (2011). Te Aka-Māori-English, English-Māori dictionary. Auckland, New Zealand: Pearson.

Morgan, R. (n.d.). 200 years of Christianity in New Zealand. Inside Life, 2, 3-8. Retrieved from http://www.insidelife.org.nz/files / 8699/InsideLife2 1\%202 00Years.pdf

Morgan, J. (1859, 10 May). J. Morgan to C. W. Richmond [Letter]. Wellington, New Zealand: Alexander Turnbull Library.

Mosse, D. (1994). The politics of religious synthesis: Roman Catholicism and Hindu village society in Tamil Nadu, India. In C. Stewart \& R. Shaw (Eds.), Syncretism/antisyncretism: The politics of religious synthesis (pp. 85-107). London, England: Routledge.

Moura-Koçoğlu, M. (2011). Narrating indigenous moderntities: Transcultural dimensions in contemporary literature. Amsterdam, The Netherlands \& New York, NY: Rodopi.

Moxon, D. (2014). Tarore and the spread of the gospel (Waikato). Retrieved from http://www.nzcms.org.nz/200-years/2014pilgrimage/2014-tarore/

Muir, S. A. (1993, November). Visual argument for social ends: Captain Planet and the integration of environmental values. Paper presented at the 79th Annual Convention of the Speech Communication Association, Miami, FL. 
Mullins, M. R. (2001). Syncretistic movements. In S. W. Sunquist (Ed.), Evangelical Dictionary of Asian Christianity (pp. 809-810). Grand Rapids, MI: William B Eerdsman.

Murphy, J. M. (2012). Santa Barbara Africana: Beyond syncretism in Cuba. In D. Lindenfeld \& M. Richardson (Eds.), Beyond conversion and syncretism: Indigenous encounters with missionary Christianity, 1800-2000 (pp. 137-166). New York, NY: Berghahn Books.

Nagy, S. (2012). Brompon: The Smith legacy. Victoria, BC: Trafford.

Neich, R. (1993). Painted histories: Early Maori figurative painting. Auckland, New Zealand: Auckland University Press.

Nepe, T. (1991). E hao nei e tenei reanga: Te toi huarewa tipuna; Kaupapa Mãori, an educational intervention system (Unpublished master's thesis). The University of Auckland, Auckland, New Zealand.

Newhouse, W. (2016). Believing part-way: Book of Mormon and postsecular America. In M. E. Shaw \& H. Welker (Eds.), Singing and dancing to The Book of Mormon: Critical essays on the broadway musical (pp. 79-91). Lanham, MD: Rowman \& Littlefield.

Newland, W. (1868). Expedition to Turanganui. Puke Ariki Museum (MSS 018), New Plymouth, New Zealand.

Newman, K. (2012). Rātana, the prophet: Mā te wā-the sign of the broken watch. In H. Morrison, L. Paterson, B. Knowles \& M. Rae (Eds.), Mana Mãori and Christianity (pp. 243264). Wellington, New Zealand: Huia.

Nibley, H. (1968). Prolegomena to any study of the Book of Abraham. Brigham Young University Studies, 8(2), 171-178.

Nicholls, B. J. (1979). Contextualization: A theology of gospel and culture. Downers Grove, IL: InterVarsity Press.

Noble, A. (1998). South Asian sacred places. Journal of Cultural Geography, 17(2), 1-3.

Norget, K. (2009). Decolonization and the politics of syncretism: The Catholic church, indigenous theology and cultural autonomy in Oaxaca, Mexico. In D. Kapoor (Ed.), Education, decolonization and development: Perspectives from Asia, Africa and the Americas (pp. 75-93). Rotterdam, Netherlands: Sense Publishers.

Oakes, L. (1997). Prophetic charisma: The psychology of revolutionary religious personalities. Syracuse, NY: Syracuse University Press. 
Oaks, D. H. (2010). The gospel culture. Retrieved from https://www.lds.org/study/ensign/2012/03/the-gospelculture?lang=eng

Office of the Government. (1865). The Committee of Ngatiawa, Whakatohea, Urewera, Taranaki. Auckland, New Zealand: Author.

Ó Gráda, C. (1989). The great Irish famine. Cambridge, England: Cambridge University Press.

Oliver, S. (1990a). Te Kani, Hirini. Te Ara-Encyclopedia of New Zealand.

Retrieved from https://teara.govt.nz/en/biographies/1t40/te-kani-hirini

Oliver, S. (1990b). Te Rauparaha, Tamihana. Te AraEncyclopedia of New Zealand. Retrieved from https://teara.govt.nz/en/biographies/1t75/te-rauparahatamihana

Oliver, S. (2001). Te Kani-a-Takirau. Te Ara-Encyclopedia of New Zealand. Retrieved from https://teara.govt.nz/en/biographies/1t41/te-kani-atakirau

Olmos, M. F. \& Paravisini-Gebert, L. (2003). Creole religions of the Caribbean: An introduction from Vodou and Santeria to Obeah and Espiritismo. New York, NY: New York University Press.

O'Malley, V. (2012). The meeting place: Mãori and Pākehā encounters, 1642-1840. Auckland, New Zealand: Auckland University Press.

O'Malley, V. (2014). Beyond the imperial frontier: The contest for colonial New Zealand. Wellington, New Zealand: Bridget Williams Books.

Orange, C. (1987). The Treaty of Waitangi. Wellington, New Zealand: Allen \& Unwin.

Orange, C. (1997). The Māori people and the British Crown (1769-1840). In K. Sinclair (Ed.), The Oxford illustrated history of New Zealand (pp. 21-48). Melbourne, Australia: Oxford University Press.

Orbell, M. (1998). The concise encyclopedia of Maori myth and legend. Christchurch, New ZealandL Canterbury University Press.

Orta, A. (2004). Catechizing culture: Missionaries, Aymara, and the 'new evangelization'. New York, NY: Columbia University Press.

Osborne, J. (1995). One of us. Philadelphia, PA: The Crawlspace. 
O'Sullivan, D. (2018). Māori, the state and self-determination in the neoliberal age. In D. Howard-Wagner, M. Bargh \& I. Altamirano-Jiménez (Eds.), The neoliberal state, recognition and indigenous rights: New paternalism to new imaginings (pp. 241-256). Canberra, Australia: ANU Press.

O’Sullivan, V. (1976). James K. Baxter. Wellington, New Zealand: Oxford University Press.

Owens, J. M. R. (1974). Prophets in the wilderness: The Wesleyan mission to New Zealand, 1819-27. Auckland, New Zealand: Auckland University Press.

Paama-Pengelly, J. (2010). Māori art and design: Weaving, painting, carving and architecture. Auckland, New Zealand: New Holland.

Palmer, P. (2001). Language and conquest in early modern Ireland: English renaissance literature and Elizabethan imperial expansion. Cambridge, England: Cambridge University Press.

Panapa, W. N. (n.d.). Translation of 'E tipu e rea'. In The story of 'Arohanui ki te tangata'-The meeting house of 'Goodwill to all men'. Wellington, New Zealand.

Panikkar, R. (1975). Some notes on syncretism and eclecticism related to the growth of human consciousness. In B. A. Pearson (Ed.), Religious syncretism in antiquity: Essays in conversation with Geo Widengren (pp. 47-62). Missoula, MT: Scholars Press.

Pannenberg, W. (1970). Basic questions of theology (Vol. 2). London, England: SCM Press.

Papa, R. \& Meredith, P. (2012). Kingitanga-The Māori King movement. Te Ara-Encyclopedia of New Zealand. Retrieved from https://teara.govt.nz/en/kingitanga-themaori-king-movement

Parker, T. (1987). And not to yield: The story of a New Zealand family 1840-1940. Auckland, New Zealand: Bateman.

Parker, T., Lopez, R. \& Stone, M. (2011). The Book of Mormon. New York, NY: Harper Collins.

Parker, T., Lopez, R. \& Stone, M. (2012). The Book of Mormon: The testament of a broadway musical. New York, NY: Harper Collins.

Paterson, L. (2008). Māori 'conversion' to the rule of law and nineteenth-century imperial loyalties. Journal of Religious History, 32(2), 216-233. 
Paterson, L. (2010). Print culture and the collective Māori consciousness. Journal of New Zealand Literature, 28(2), 105-129.

Paul, G. M. (1995). Te Houhi and Waiohau $1 B$ (Wai 212). Murupara, New Zealand: Te Runanganui o Te Ika Whenua.

Paulsen, D. L. (1995). The doctrine of divine embodiment: Restoration, Judeo-Christian, and philosophical perspectives. BYU Studies Quarterly, 35(4).

Phillips, J. (2015). Irish. Retrieved from https://teara.govt.nz/en/irish

Pompallier, J. B. F. (1841, 29 January). Instructions for mission work [Manuscript] (K. Morgan, Trans.). Auckland Catholic Diocesan Archives, Auckland, New Zealand.

Pompallier, J. B. F. (1863, 21 December). Pompallier to all the Catholic Fathers of the Tribes at Rangiaohia [Rangiaowhia] and to all the Members of the Catholic Flock in the Diocese, Auckland. In A letter of the Catholic Bishop of Auckland to the Catholic Fathers of Maori tribes for the Pacification and Christian Happiness of New Zealand.

Pool, D. I. (1977). The Maori population of New Zealand 17691971. Auckland, New Zealand: Auckland University Press.

Pope Francis (2015). Laudato si'. Vatican: Vatican Press.

Pringle, T. (ca. 1905). Group outside a meeting house at Rangitahi pa, Murupara [photograph]. A. E. Birch collection. (1/1-007027-G). Alexander Turnbull Library, Wellington, New Zealand.

"Prisoners' Work List 1" (1866, March-1867, March). Army Department 31:16, Archives New Zealand, Wellington, New Zealand.

Proceedings of the General Synod of the Church of the Province of New Zealand (1880). Wellington, New Zealand.

Purchas, H. T. (1914). A history of the English Church in New Zealand. Christchurch, New Zealand: Simpson \& Williams.

Pye, M. (2004). Syncretism and ambiguity. In A. M. Leopold \& J. S. Jensen (Eds.), Syncretism in religion: A reader (pp. 5967). New York, NY: Routledge.

$R \quad v$ Symonds (1847) NZPCC 387. Retrieved from http://www.nzlii.org/cgibin/sinodisp/nz/cases/NZHC/1847/1.html?query=symon ds

Rae, M. (2012). The subversive theology of Rua Kēnana. In H. Morrison, L. Paterson, B. Knowles \& M. Rae (Eds.), Mana 
Māori and Christianity (pp. 223-242). Wellington, New Zealand: Huia.

Räisänen, H. (1982). Jesus and the food laws: Reflections on Mark 7:15. Journal of the Study of the New Testament, 16, 79-100.

Raj, S. J. (2002). The Ganges, the Jordan, and the mountain: The three strands of Santal in popular Catholicism. In S. J. Raj \& C. G. Dempsey (Eds.), Popular Christianity in India: Riting between the lines (pp. 39-60). Albany, NY: State University of New York Press.

Rangiwai, B. (2018a). Atuatanga. Te Kaharoa: The eJournal on Indigenous Pacific Issues, 11(1), 222-224. Retrieved from: https://www.tekaharoa.com/index.php/tekaharoa/article/ view/209

Rangiwai, B. (2018b). "God is..." : A personal theology based on stories from my grandmother. Te Kaharoa: The eJournal on Indigenous Pacific Issues, 11(1), 171-172. Retrieved from: https://www.tekaharoa.com/index.php/tekaharoa/article/ view/179/159

Rangiwai, B. (2018c). Karaititanga: Some reflections on my Christology. Te Kaharoa: The eJournal on Indigenous Pacific Issues, 11(1), 591-603. Retrieved from: https://www.tekaharoa.com/index.php/tekaharoa/article/ view $/ 238$

Ransford, K. R. \& Crawford, A. (2018). Narrative possibilities and potential for understanding a twenty-first century Christian spiritual journey. In J. M. Luetz, T. Dowden \& B. Norsworthy (Eds.), Reimagining Christian education: Cultivating transformative approaches (pp. 197-206). Singapore, Malaysia: Springer.

Reed, A. W. (2004). Reed book of Mãori mythology. Auckland, New Zealand: Reed.

Reedy, T. M. (2017). Ngāti Porou-Ancestors. Retrieved from http://www.TeAra.govt.nz/en/music/643/paikea

Reilly, M. (2018). Te tìmatanga mai o te ao: The beginning of the world. In M. Reilly, S. Duncan, G. Leoni, L. Paterson, L. Carter, M. Rātima \& P. Rewi (Eds.), Te Kōparapara: An introduction to the Māori world (pp. 12-39). Auckland, New Zealand: Auckland University Press.

Reilly, M. P. J. (2004). Te tīmatanga mai o ngā atua. In T. M. Ka'ai, J. C. Moorfield, M. P. J. Reilly \& S. Mosley (Eds.), Ki te whaiao: An introduction to Māori culture and society (pp.1-12). Auckland, New Zealand: Pearson. 
Reilly, M. P. J. (2010). Tuakana-Teina relationships and leadership in ancient Mangaia and Aotearoa. The Journal of Pacific History, 45(2), 211-227.

Rewi, P. (2010). Karakia Māori: Māori invocations to spiritual authorities. He Pukenga Kōrero: A Journal of Māori Studies, 9(2), 15-20.

Ringgren, H. (1969). The problem of syncretism. In S. S. Hartman (Ed.), Syncretism (pp. 7-14). Stockholm, Sweden: Almqvist \& Wiksell.

Ritchie, J., Morrison, S., Vaioleti, T. \& Ritchie, T. (2013). Transgressing boundaries of private and public: Autoethnography and intercultural funerals. Studies in Symbolic Interaction, 40, pp. 95-126.

Roberts, M. (2013). Ways of seeing: Whakapapa. Sites: A Journal of Social Anthropology and Cultural Studies, 10(1), 93-120.

Robinson, B. (2004). Christians meeting Hindus: An analysis and theological critique of the Hindu-Christian encounter in India. Oxford, England: Regnum Books.

Robley, H. G. (ca. 1863). A Maori child feeding a tohunga with food on the end of a stick [watercolour]. (A-080-003). Alexander Turnbull Library, Wellington, New Zealand.

Robson, C. (1866). Māori Hauhau prisoners on Napier foreshore [photograph]. C. G. Coxhead collection. (1/2-118691-G). Alexander Turnbull Library, Wellington, New Zealand.

Rolleston, W. (1868, January 28). [Letter from W. Rolleston to Thomas]. Army Department (31:16), Archives New Zealand, Wellington, New Zealand.

Rogers, L. M. (1973). Te Wiremu: A biography of Henry Williams. Christchurch, New Zealand: Pegasus.

Rose, D. B. (2000). Dingo makes us human: Life and land in an Australian Aborginal culture. Cambridge, UK: Cambridge University Press.

Rosen, S. J. (2006). Essential Hinduism. Westport, CT: Praeger.

Rosenfeld, J. E. (1995). Pai Marire: Peace and violence in a New Zealand millenarian tradition. Terrorism and Political Violence, 7(3), 83-108.

Rosenfeld, J. E. (1996). Pai Marire: Peace and violence in a New Zealand millenarian tradition. In M. Barkun (Ed.), Millennialism and violence (pp.83-108). London, England: Frank Cass \& Company. 
Rosenfeld, J. E. (1999). The island broken in two halves: Land and renewal movements among the Maori of New Zealand. University Park, PA: Pennsylvania State University Press.

Rosenfeld, J. E. (2011). Nativist millennialism. In C. Wessinger (Ed.), The Oxford handbook of millennialism (pp. 89-109). New York, NY: Oxford University Press.

Ross, M. (2018). [Review of the book Tupuna awa: People and politics of the Waikato River]. Journal of Indigenous Wellbeing, 3(1), 69-70.

Ross, W. Hugh. (1966). Te Kooti Rikirangi: General and prophet. Auckland, New Zealand: Collins.

Roxburgh, I. (1985). The Ringatu movement: A culture shock in New Zealand/Aotearoa. Christchurch, New Zealand: Cadsonbury.

Royal, T. C. (2007a). Kaitiakitanga-Guardianship and conservation. Te Ara-Encyclopedia of New Zealand. Retrieved from https://teara.govt.nz/en/kaitiakitangaguardianship-and-conservation

Royal, T. C. (2007b). Te Ao Marama-The natural world-The traditional Māori worldview. Te Ara-Encyclopedia of New Zealand. Retrieved from https://teara.govt.nz/en/te-aomarama-the-natural-world/page-1

Royal, T. C. (2012). Politics and knowledge: Kaupapa Māori and mātauranga Māori. New Zealand Journal of Educational Studies, 47(2), 30-37.

Royal, T. C. (2015). Hawaiki. Retrieved from https://teara.govt.nz/en/hawaiki

Royal, T. C. (2017). Waikato tribes-The King movement. Retrieved from https://teara.govt.nz/en/photograph/1736/te-paki-o$\underline{\text { matariki }}$

Rubin, H. \& Rubin, I. (2005). Qualitative interviewing: The art of hearing data. Thousand Oaks, CA: Sage.

Rudolph, K. (2004). Syncretism: From theological invective to a concept in the study of religion. In A. M. Leopold \& J. S. Jensen (Eds.), Syncretism in religion: A reader (pp. 68-85). New York, NY: Routledge.

Russell, A. H. (1866, February). [Letter from A. H. Russell to Capt. W. E. Thomas]. Army Department (31:14), Archives New Zealand, Wellington, New Zealand.

Ryan, P. M. (2001). The Reed dictionary of modern Mãori. Auckland, New Zealand: Reed. 
Salazar, V. S. (1997). The invasion of Christianity into the world of the Mayas. In G. Cook (Ed.), Crosscurrents in indigenous spirituality: Interface of Maya, Catholic and Protestant worldviews (pp. 36-48). Leiden, Netherlands: E. J. Brill.

Salmond, A. (1976). Hui: A study of Maori ceremonial gatherings (2nd ed.). Auckland, New Zealand: Reed.

Salmond, A. (1985). Maori epistemologies. In J. Overing (Ed.), Reason and morality (pp. 240-64). London, England: Routledge.

Salmond, A. (1993). Whose God, or not. Social Analysis, 34, pp. $50-55$.

Salmond, A. (1997). Between worlds: Early exchanges between Maori and Europeans 1773-1815. Auckland, New Zealand: Penguin.

Salmond, A. (2017). Tears of Rangi: Experiments across worlds. Auckland, New Zealand: Auckland University Press.

Sanderson, K. (1983). Maori Christianity on the East Coast 1840-1870. New Zealand Journal of History, 17(2), pp. $166-184$.

Schmidt-Leukel, P. (2009). Transformation by integration: How inter-faith encounter changes Christianity. London, England: SCM Press.

Schreiter, R. J. (1985). Constructing local theologies. Maryknoll, NY: Orbis.

Schreiter, R. J. (1997). The new catholicity: Theology between the global and the local. Maryknoll, NY: Orbis.

Schwaller, J. F. (2006). Syncretism. In J. M. Francis (Ed.), Iberia and the Americas: Culture, politics, and history: A multidisciplinary encyclopedia (Vol. 3) (pp. 993-995). Santa Barbara, CA: ABC-CLIO.

Sciascia, P. \& Meredith, P. (2014). Waiata hou-Contemporary Māori songs-Waiata-a-ringa-Māori action songs. Te AraEncyclopedia of New Zealand. Retrieved from http://www.TeAra.govt.nz/en/interactive/44806/paikea

Servant, C. (1973). Customs and habits of the New Zealanders 1838-42 (J. Glasgow, Trans.). Wellington, New Zealand: A. H. \& A. W. Reed.

Sharma, A. (2003). A study of Hinduism. Chapel Hill, NC: University of Carolina Press.

Shaw, R. \& Stewart, C. (1994). Introduction: Problematizing syncretism. In C. Stewart \& R. Shaw (Eds.), Syncretism/anti-syncretism: The politics of religious synthesis (pp. 1-26). New York, NY: Routledge. 
Sheth, N. (2002). Hindu avatāra and Christian incarnation: A comparison. Philosophy East and West, 52(1), 98-125.

Shils, E. (1981). Tradition. Chicago, IL: The University of Chicago Press.

Shohat, E. \& Stam, R. (2014). Unthinking eurocentricism: Multiculturalism and the media. London, England: Routledge.

Simmons, D. R. (1986). Iconography of New Zealand Maori religion. Leiden, Netherlands: E. J. Brill.

Simmons, E. R. (1978). A brief history of the Catholic Church in New Zealand. Auckland, New Zealand: Catholic Publications Centre.

Simmons, E. R. (1984). Pompallier: Prince of bishops. Auckland, New Zealand: CPC Publishing.

Simon, J. \& Smith, L. T. (2001). A civilising mission: Perceptions and representations of the New Zealand native school system. Auckland, New Zealand: Auckland University Press.

Sinclair, K. (1974). The origins of the Maori wars. Auckland, New Zealand: Auckland University Press.

Sinclair, K. (2002). Prophetic histories: The people of the Mãramatanga. Wellington: Bridget Williams.

Sinclair, K. P. (1993). The Maori tradition of prophecy: Religion, history, and politics in New Zealand. In V. S. Lockwood, T. G. Harding \& B. J. Wallace (Eds.), Contemporary Pacific societies: Studies in development and change (pp. 321-334). Englewood Cliffs, NJ: Prentice Hall.

Sirvent, R. \& Baker, N. (2016). Reinhold Niebuhr and religious foolishness: 'A Mormon just believes'. In M. E. Shaw \& H. Welker (Eds.), Singing and dancing to The Book of Mormon: Critical essays on the broadway musical (pp. 43-59). Lanham, MD: Rowman \& Littlefield.

Sissons, J. (1998). The traditionalisation of the Maori meeting house. Oceania, 69(1), 36-46.

Slater, M., Stephens, T. (Producers), \& Ward, V. (Director). (2008). Rain of the children [Motion picture]. Auckland, New Zealand: Wayward Films, Forward Films, Vincent Ward Films.

Smith, J. S. (1835). History, 1838-1856, volume B-1 (1 September 1834 - 2 November 1838). Retrieved from http://www.josephsmithpapers.org/papersummary/history-1838-1856-volume-b-1-1-september1834-2-november-1838/50 
Smith, K. C. (2004). The spiritual millionaire: The spirit of wisdom will make you rich. Ormond Beach, FL: WKU Publishing.

Smith, L. T. (1999). Decolonizing methodologies. Dunedin, New Zealand: Otago University Press.

Smith, L. T. (2005). On tricky ground: Researching the native in the age of uncertainty. In N. K. Denzin \& Y. S. Lincoln (Eds.), The Sage handbook of qualitative research (3rd ed.) (pp. 85-107). Thousand Oaks, CA: Sage.

Smith, L. T. (2011). Story-ing the development of Kaupapa Māori research. In J. Hutchings, H. Potter \& K. Taupo (Eds.), Proceedings of the Kei tua o te pae hui conference: The challenge of Kaupapa Māori research in the 21st century (pp. 10-15). Wellington, New Zealand: New Zealand Council for Educational Research.

Sorrenson, M. P. K. (1979). Maori origins and migrations: The genesis of some Pakeha myth and legends. Auckland, New Zealand: Auckland University Press.

Soutar, M. (2000). Ngāti Porou leadership: Rāpata Wahawaha and the politics of conflict: 'Kei te ora nei hoki tātou, me tō tâtou whenua' (Unpublished doctoral thesis). Massey University, Palmerston North, New Zealand.

Sowande, B. (1996). Syncretic aesthetics in modern Nigerian theatre. In P. O. Stummer \& C. Balme (Eds.), Fusion of cultures? (pp. 19-24). Amsterdam, Netherlands: Rodopi.

Sparkes, A. (2000). Autoethnography and narratives of self: Reflections on critical action. Sociology of Sport Journal, 17(1), p. 21-43.

Speake, J. (2015). Oxford Dictionary of Proverbs (6th ed.). Oxford, England: Oxford University Press.

Staffner, H. (1987). Jesus Christ and the Hindu community: Is a synthesis of Hinduism and Christianity possible? Anand, India: Gujarat Sahitya Prakash.

Statistics New Zealand. (2014). 2013 Census quickstats about culture and identity - tables. Retrieved from: http://www.stats.govt.nz/Census/2013-census/profileand-summary-reports/quickstats-culture-identity.aspx

Stenhouse, J. (2018). Religion and society-Māori religion. Te Ara-Encyclopedia of New Zealand. Retrieved from https://teara.govt.nz/en/religion-and-society

Stenhouse, J. \& Paterson, L. (2004). Ngā poropiti me ngā hāhiProphets and the churches. In T. M. Ka'ai, J. C. Moorfield, M. P. J. Reilly \& S. Mosley (Eds.), Ki te whaiao: An 
introduction to Māori culture and society (pp. 171-180). Auckland, New Zealand: Pearson.

Stewart, T. K. (2001). In search of equivalence: Conceiving Muslim-Hindu encounter through translation theory. History of Religions, 40(3), 260-287.

Stewart, C. (2004). Relocating syncretism in social science discourse. In A. M. Leopold \& J. S. Jensen (Eds.), Syncretism in religion: A reader (pp. 264-285). New York, NY: Routledge.

Stokes, E. (1990). Te waharoa wiremu tamihana tarapipi. Te Ara-Encyclopedia of New Zealand. Retrieved from https:/ / teara.govt.nz/en/biographies / 1t82/te-waharoawiremu-tamihana-tarapipipi

Stokes, E., Milroy, W. J., \& Melbourne, H. (1986). People, land and forests of Te Urewera. Hamilton, New Zealand: University of Waikato.

Stump, R. W. (2008). Geography of religion: Faith, place, and space. New York, NY: Rowman \& Littlefield.

Sundt, R. A. (2010). Whare karakia: Māori church building, decoration and ritual in Aotearoa New Zealand 1834-1863. Auckland, New Zealand: Auckland University Press.

Sung Park, A. (2001). A theology of the way (Tao). Interpretation: A Journal of Bible and Theology, 55, 389-399.

Swadener, B. B. \& Mutua, K. (2008). Decolonizing performances: Deconstructing the global postcolonial. In N. K. Denzin, Y. S. Lincoln \& L. T. Smith (Eds.), Handbook of critical and indigenous methodologies (pp. 31-43). Los Angeles, CA: Sage.

Swami Bhaskarananda. (2005). The essentials of Hinduism: A comprehensive overview of the world's older religion. Seattle, WA: Viveka Press.

Tamahori, J. T. (1990). Turei, Mohi. Te Ara-Encyclopedia of New Zealand. Retrieved from https://teara.govt.nz/en/biographies/1t113/turei-mohi

Tāmihana, W. (1861, 7 June). Wiremu Tamihana to the Governor. Appendices to the Journals of the House of Representatives, E-1B, p. 19.

Tapsell, P. (2018). Marae. In M. Reilly, S. Duncan, G. Leoni, L. Paterson, L. Carter, M. Rātima \& P. Rewi (Eds.), Te kōparapara: An introduction to the Māori world (pp. 102120). Auckland, New Zealand: Auckland University Press. 
Tarei, W. (2011). A church called Ringatu. In M. King (Ed.), Te Ao Hurihuri: Aspects of Maoritanga (pp.138-143). Auckland, New Zealand: Penguin.

Tate, H. (2012). He puna iti $i$ te ao mārama: A little spring in the world of light. Auckland, New Zealand: Libro.

Taylor, R. (1845). A sketch taken on the road to Rotokakahi; he Tuahu he Pahere ranei [sketch]. (E-296-q-057-2). Alexander Turnbull Library, Wellington, New Zealand.

Taylor, R. (1855). Te Ika a Maui or New Zealand and its inhabitants: Ilustrating the origin, manners, customs, mythology, religion, rites, songs, proverbs, fables, and language of the natives; together with the geology, natural history, productions, and climate of the country, its state as regards Christianity, sketches of the principal chief, and their present position. London, England: Wertheim \& Macintosh.

Taylor, D. J. (2009). Jean Baptiste Francois Pompallier-Loved and lamented through the generations in New Zealand: An overview and appraisal of Bishop Pompallier's mission to Maori, its continuation and the return of his body to New Zealand (Unpublished master's thesis). Massey University, Palmerston North, New Zealand.

Te Kaawa, W. (2012). A gifted people: Māori and Pākehā covenants within the Presbyterian Church. In H. Morrison, L. Paterson, B. Knowles \& M. Rae (Eds.), Mana Māori and Christianity (pp. 3-22). Wellington, New Zealand: Huia.

Te Kooti, A. T. (1866-1890). Notebook [transcribed by Hamiora Aparoa]. MSS \& Archives C-35, Māori Archives and Manuscripts, University of Auckland, Auckland, New Zealand.

Tennant, M. (1999). Pakeha deaconesses and the New Zealand Methodist Mission to Maori, 1893-1940. The Journal of Religious History, 23(3), 309-326.

Te Rangi Hiroa. (1952). The coming of the Māori. Wellington, New Zealand: Whitcombe \& Tombs.

Te Rire, H. (2012). Hihita me ngā Tamariki o te Kohu. In H. Morrison, L. Paterson, B. Knowles \& M. Rae (Eds.), Mana Māori and Christianity (pp. 205-222). Wellington, New Zealand: Huia.

Te Runanganui o Ngāti Porou (2019). Taumatakura and Ngati Porou spirituality. Retrieved from https://ngatiporou.com/article/taumatakura-and-ngatiporou-spirituality 
The Church of Jesus Christ of Latter-Day Saints. (1985). Hymns of the Church of Jesus Christ of Latter-Day Saints. Salt Lake City, UT: Author.

The Church of Jesus Christ of Latter-Day Saints. (1986). Uniform system for teaching the gospel. Salt Lake City, UT: Author.

The Church of Jesus Christ of Latter-Day Saints. (2014a). Becoming like God. Retrieved from https://www.lds.org/topics/becoming-like-god?lang=eng

The Church of Jesus Christ of Latter-Day Saints. (2014b). Translation and historicity of the Book of Abraham. Retrieved from https://www.lds.org/topics/translationand-historicity-of-the-book-of-abraham?lang=eng

The Church of Jesus Christ of Latter-Day Saints. (2018a). Race and the priesthood. Retrieved from https://www.lds.org/topics/race-and-thepriesthood?lang=eng

The Church of Jesus Christ of Latter-Day Saints. (2018b). Same-sex attraction. Retrieved from https://www.lds.org/topics/same-sex-attraction?lang=eng

The story of Paikea and Ruatapu. (1962, September). Te Ao Hou, 40, 6.

Thomas, R. (1891). Eripitana wharenui [watercolour]. (B-159007). Alexander Turnbull Library, Wellington, New Zealand.

Thompson, J. (1969). Some reasons for the failure of the Roman Catholic mission to the Maoris 1838-1860. New Zealand Journal of History, 3(2), 166-174.

Tishken, J. E. (2007). The history of prophecy in West Africa: Indigenous, Islamic, and Christian. History Compass, 5(5), $1468-1482$.

Torr, S. C. (2017). Lamenting in tongues: Glossolalia as a pneumatic aid to lament. Journal of Pentecostal Theology, 26(1), 30-47.

Tregear, E. (1904). The Maori race. Whanganui, New Zealand: Dudingston Willis.

True Tao. (2016). Three treasures. Retrieved from http://truetao.org/tao/three-treasures/

Tucker, H. W. (1879). Memoir of the life and episcopate of George Augustus Selwyn. London, UK: William Wells Gardner.

Turner, N. (1838, 20 January). Nathaniel Turner to WMS secretaries [Letter]. WMS NZ Correspondence, microfiche collection 3, reel 19, Alexander Turnbull Library, Wellington, New Zealand. 
Vallée, G. (1999). The shaping of Christianity: The history and literature of its formative centuries (100-800). New York, NY: Paulist Press.

van Dijk, R. (2003). Pentecostalism and the politics of prophetic power: Religious modernity in Ghana. In N. Kastfelt (Ed.), Scriptural politics: The Bible and the Koran as political models in the Middle East and Africa (pp. 155-184). London, England: Hurst \& Company.

van Meijl, T. (2009). The Poukai ceremony of the Māori King movement: An ethnohistorical interpretation. The Journal of the Polynesian Society, 118(3), 233-258.

van Orden, B. A. (1994). What do we know about the location of the Garden of Eden? Retrieved from https://www.lds.org/ensign/1994/01/i-have-aquestion/what-do-we-know-about-the-location-of-thegarden-of-eden?lang=eng

Vanden Berg, T. M. (2005). Culture, Christianity, and witchcraft in a West African context. In L. Sanneh \& J. A. Carpenter (Eds.), The changing face of Christianity: Africa, the West, and the world (pp. 45-62). Oxford, England: Oxford University Press.

van der Leeuw, G. (2004). The dynamism of religions: Syncretism: Mission. In A. M. Leopold \& J. S. Jensen (Eds.), Syncretism in religion: A reader (pp. 98-102). New York, NY: Routledge.

van der Veer, P. (1994). Syncretism, multiculturalism and the discourse of tolerance. In C. Stewart \& R. Shaw (Eds.), Syncretism/anti-syncretism: The politics of religious syncretism (pp. 196-211). London, England: Routledge.

Vilaça, A. \& Wright, R. M. (Eds.). (2009). Native Christians: Modes and effects of Christianity among indigenous peoples of the Americas. Surrey, England: Ashgate.

Visser't Hooft, W.A. (1963). No other name: The choice between syncretism and Christian universalism. London, England: SCM Press.

Volkner, C. S. (1864, 16 February). Rev. C. S. Volkner to Governor Grey [Letter]. Archives New Zealand (G 13/3.89), Wellington, New Zealand.

Wakefield, E. J. (1845). Adventure in New Zealand, from 1839 to 1844 with some account of the beginning of the British colonization of the islands. London, UK: John Murray.

Walker, R. J. (1984). The genesis of Māori activism. The Journal of the Polynesian Society, 93(3), 267-281. 
Walker, R. (2002). He tipua: The life and times of Sir Āpirana Ngata. Auckland, New Zealand: Penguin.

Walker, R. (2004). Ka whawhai tonu matou: Struggle without end. Auckland, New Zealand: Penguin.

Wallace, A. F. C. (1956). Revitalization movements. American Anthropologist, 58(2), 264-281.

Walls, A. F. (2002). The cross-cultural process in Christian history: Studies in the transmission and appropriation of faith. Maryknoll, NY: Orbis.

Walzer, M. (1985). Exodus and revolution. New York, NY: Basic Books.

Wan, E. (2003). Jesus Christ for the Chinese: A contextual reflection. Global Missiology, 1(1), 1-12. Retrieved from http://ojs.globalmissiology.org/index.php/english/issue/vi ew $/ 27$

Ward, A. (1978). A show of justice: Racial 'amalgamation' in nineteenth century New Zealand. Auckland, New Zealand: Auckland University Press.

Ward, V. (Director). (2008). Rain of the children [Motion picture]. Auckland, New Zealand: Wayward Films, Forward Films, Vincent Ward Films.

Ware, T. (1993). The Orthodox Church. London, England: Penguin.

Webber, D. J. \& Freke, M. (2006). Church organists: Analysing their willingness to play. The Journal of Socio-Economics, 35, 854-867.

Webster, P. (1979). Rua and the Maori millennium. Wellington, New Zealand: Victoria University Press.

White, B. H. (2010). A historical analysis of how Preach My Gospel came to be (Unpublished master's thesis). Brigham Young University, Provo, UT.

Whitehouse, H. (2000). Arguments and icons: Divergent modes of religiosity. Oxford, England: Oxford University Press.

Whiteley, J. (1857, 17 August). J. Whiteley to C. W. Richmond. [Letter]. Richmond-Atkinson Papers, Alexander Turnbull Library, Wellington, New Zealand.

Whitinui, P. (2014). Indigenous autoethnography: Exploring, engaging, and experiencing 'self' as a native method of inquiry. Journal of Contemporary Ethnography, 43(4), 456487.

Wild, R. (1986). His face shone like the sun: Encountering the transfigured Christ in scripture. New York, NY: Alba House. 
Williams, H. (1999). Te Kooti-Te tangata. In W. Curnow \& L. Davis (Eds.), Te Tangi a te Matuhi (pp. 75-82). Auckland, New Zealand: Jack Books.

Williams, J. (2004). Papa-tūā-nuku: Attitudes to land. In T. M. Ka'ai, J. C. Moorfield, M. P. J. Reilly \& S. Mosley (Eds), Ki te whaiao: An introduction to Mãori culture and society (pp. 50-60). Auckland, New Zealand: Pearson.

Williams, W. (1847, 12 July). William Williams to the CMS. Church Missionary Society Archives, micro. coll. 4, reel 62, (C/N/095), Alexander Turnbull Library, Wellington, New Zealand.

Williams, W. (1867). Christianity among the New Zealanders. London, UK: Seeley, Jackson \& Halliday.

Willis, J. (2018). The problem of presence: A study of glossolalia and its implications for religious ethnography. Logos: A Journal of Undergraduate Research, 207-222.

Wilson, F. J. (1861). Extracts of letters from New Zealand on the war question. Hocken Pamphlets (Vol. 24, No 7). London, UK.

Winiata, M. (1967). The changing role of the leader in Maori society: A study in social change and race relations. Auckland, New Zealand: Blackwood \& Janet Paul.

Woodard, R. D. (2007). The Cambridge companion to Greek mythology. Cambridge, England: Cambridge University Press.

Woodard, W. (2014). Politics, psychotherapy, and the 1907 Tohunga Suppression Act. Psychotherapy and Politics International, 12(1), 39-48.

Wright, H. M. (1959). New Zealand, 1769-1840: Early years of Western contact. Cambridge, MA: Harvard University Press.

Yate, W. (1835). An account of New Zealand and of the Church Missionary Society's mission in the northern island (2nd ed.). London, United Kingdom: R. B. Seely \& W. Burnside.

Yates, T. (2013). The conversion of the Mãori: Years of religious and social change, 1814-1842. Cambridge, England: William B. Eerdmans Publishing Company.

Yong, A. (2014). The missiological spirit: Christian mission theology in the third millennium global context. Eugene, OR: Wipf \& Stock.

Zamora, L. P. (2006). The inordinate eye: New world Baroque and Latin American fiction. Chicago, IL: The University of Chicago Press. 
Zimmerman, L. J. (1997). Remythologizing the relationship between Indians and archaeologists. In N. Swidler, K. E. Dongoske, R. Anyon \& A. S. Downer (Eds.), Native Americans and archaeologists: Stepping stones to common ground (pp. 44-56). Walnut Creek, CA: AltaMira Press. 